\title{
Oxygen solubility and speciation in sulphide-rich mattes
}

\author{
Raúl O.C. Fonseca ${ }^{\text {a,b,* }}$, Ian H. Campbell ${ }^{\text {b }}$, Hugh St.C. O’Neill ${ }^{\text {b }}$, John D. Fitzgerald ${ }^{\text {b }}$ \\ a Steinmann Institut für Geologie, Mineralogie und Paläontologie, Rheinische Friedrich-Wilhelms Univerisität Bonn, Germany \\ ${ }^{\mathrm{b}}$ Research School of Earth Sciences, Australian National University, Canberra ACT, Australia
}

Received 10 October 2007; accepted in revised form 17 March 2008; available online 1 April 2008

\begin{abstract}
Sulphide-rich liquids are common in magmatic environments forming over a wide range of temperature, pressure, $f \mathrm{O}_{2}$ and $f \mathrm{~S}_{2}$. They are economically important because they sequester valuable metals such as $\mathrm{Cu}, \mathrm{Ni}, \mathrm{Au}$ and $\mathrm{Pt}$ from silicate melts. The presence of accessory amounts of primary oxides associated with sulphide mineralisations is often ignored or unexplained. Experimental work has shown that large amounts of oxygen can dissolve into mattes at $f \mathrm{O}_{2}$ typical of terrestrial environments. At the quartz-fayalite-magnetite $f_{\mathrm{O}_{2}}$ buffer, the molar fraction of $\mathrm{O}$ in the matte exceeds that of $\mathrm{S}$, placing the composition of the matte to the magnetite side of the mss (monosulphide solid solution)-magnetite join in the Fe-S-O system. However, sulphides crystallise before magnetite in most sulphide mineralisations and are much more abundant. Moreover, the speciation of $\mathrm{O}$ in a matte is not well known. Here we report the results of an experimental study of the solubility of $\mathrm{O}$ in mattes as a function of $f \mathrm{~S}_{2}, f \mathrm{O}_{2}$, temperature, and composition. We confirm previous observations that $\mathrm{Ni}$ and $\mathrm{Cu}$ have a negative effect on the solubility of $\mathrm{O}$ in mattes. We show evidence for the existence of $\mathrm{FeSO}$ as a structural constituent of mattes in the $\mathrm{Fe}-\mathrm{S}-\mathrm{O}$ system. We present a simple parameterisation of the amount of $\mathrm{O}$ dissolved in mattes under relevant geological conditions, and use this parameterisation to discuss mechanisms for the crystallisation of primary spinels associated with sulphides in the Kambalda massive sulphide deposit (Western Australia) and the Sudbury Igneous Complex (Ontario, Canada).
\end{abstract}

(C) 2008 Elsevier Ltd. All rights reserved.

\section{INTRODUCTION}

Sulphide liquids, or mattes, occur in many magmatic settings, from $\mathrm{Cu}-\mathrm{Ni}$ massive sulphide deposits associated with ultramafic flows, to PGE-rich deposits such as the Bushveld complex (South Africa) and Sudbury (Ontario, Canada). Early experimental work by Naldrett (1969), and empirical observations, showed that magmatic sulphides are the product of the segregation of an immiscible sulphide-rich matte from a host silicate melt. The mattes sequester chalcophile metals from their parental silicate melt, which may lead to the formation of important ore deposits such as the Pt-rich Merensky Reef (e.g. Campbell et al., 1983). An immiscible FeS-rich matte can contain

\footnotetext{
* Corresponding author. Present address: Steinmann Institut für Geologie, Mineralogie und Paläontologie, Rheinische FriedrichWilhelms Univerisität Bonn, Germany. Fax: +49 (0)228 732763.

E-mail address: raul.fonseca@uni-bonn.de (R.O.C. Fonseca).
}

appreciable amounts of $\mathrm{O}$; for example, at the oxygen fugacity of the quartz-fayalite-magnetite (QFM) buffer, often thought to be typical of terrestrial crustal conditions, the matte contains a higher molar proportion of $\mathrm{O}$ than $\mathrm{S}$ (Nagamori and Kameda, 1965; Naldrett, 1969; Doyle and Naldrett, 1987; Kress, 1997; Nagamori and Yazawa, 2001; further affirmation of this perhaps surprising fact will also be presented in this study).

Furthermore, experimental data predict that at QFM, because the composition of a matte falls on the O-rich side of the magnetite-mss (monosulphide solid solution) cotetic in the $\mathrm{Fe}-\mathrm{S}-\mathrm{O}$ system (Fig. 1), the first phase to crystallise should be magnetite followed by mss, yet in natural assemblages the opposite appears to be true (Doyle and Naldrett, 1987). Two possible explanations have been proposed to explain this. Firstly, estimates of the $f \mathrm{O}_{2}$ of natural magmas are known to vary from as low as QFM-3 to as high as QFM+3 (e.g. Christie et al., 1986; Ballhaus, 1993). Monosulphide solid solution should crystallise first in magmas that formed at $f \mathrm{O}_{2}$ lower than QFM, implying that the oxi- 


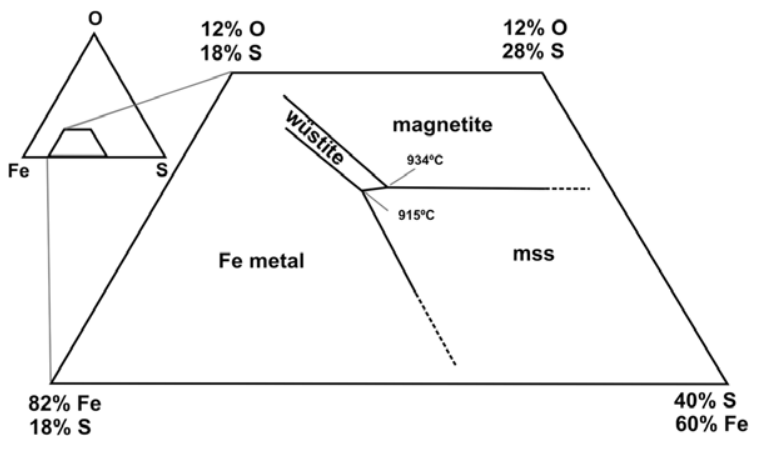

Fig. 1. Enlargement of the $\mathrm{Fe}-\mathrm{S}-\mathrm{O}$ liquidus diagram, detailing the mss-magnetite and the mss-wüstite cotectics. Modified from Naldrett (1969) and Mungall et al. (2005).

dation state of ore-forming magmas might simply be lower than QFM. Secondly, Celmer (1988) and Yoshiki-Gravelsins and Toguri (1993) have noted that at a given $f \mathrm{O}_{2}$ the oxygen content of a sulphide-rich matte depends on its $\mathrm{Fe} /(\mathrm{Ni}+\mathrm{Cu})$ ratio, with $\mathrm{O}$ being more soluble in Fe-rich compositions than in Fe-poor compositions. The presence of $\mathrm{Cu}$ and $\mathrm{Ni}$ in the matte may therefore lower its $\mathrm{O}$ content so that its bulk composition is closer to the mss field than is the case for Fe-S-O mattes sensu strictum (Naldrett, 1989).

The speciation of oxygen in mattes is not known. Most authors suggest that the composition of a matte is controlled by the following reaction:

$\mathrm{FeO}_{\text {matte }}+1 / 2 \mathrm{~S}_{2} \leftrightarrow \mathrm{FeS}$ matte $+1 / 2 \mathrm{O}_{2}$

with $\mathrm{FeO}$ as the principal $\mathrm{O}$ species in the matte, and $\mathrm{O} /$ $(\mathrm{O}+\mathrm{S})$ in the matte varying as a function of the $f \mathrm{O}_{2} / f \mathrm{~S}_{2}$ ratio (e.g. Shima and Naldrett, 1975). However, magnetite $\left(\mathrm{Fe}_{3} \mathrm{O}_{4}\right)$, not wüstite $\left(\mathrm{Fe}_{1-\mathrm{x}} \mathrm{O}\right)$ is the common iron oxide associated with magmatic sulphides (Naldrett, 1969). Kress (2000) proposed a thermodynamic model based on six matte components, $\mathrm{S}, \mathrm{Fe}, \mathrm{FeO}, \mathrm{FeO}_{1,5}, \mathrm{FeS}$ and FeOS. The ternary stoichiometry FeSO has never been recognised in either experimental work or in natural assemblages; however, it was postulated by Kress (2000) as a possible species in sulphide-rich matte since its presence provided the best fit to his associated solution model for available experimental data (Nagamori et al., 1970; Kress, 1997).

Here we report experiments in which the solubility of $\mathrm{O}$ in mattes was investigated as a function of $f \mathrm{O}_{2}, f \mathrm{~S}_{2}$, composition and temperature. We show novel evidence that FeSO is more than a convenient thermodynamic component, as described by Kress (2000), but an actual structural species in mattes in the system $\mathrm{Fe}-\mathrm{S}-\mathrm{O}$. We quantify the influence of $\mathrm{Ni}$ and $\mathrm{Cu}$ on the $\mathrm{O}$ abundances of mattes through a simple, easy-to-use parameterisation of available data. We show that $\mathrm{Ni}$, and in a lesser extent $\mathrm{Cu}$, have a negative effect on $\mathrm{O}$ solubility in a sulphide-rich matte, consistent with previous studies (Celmer, 1988; Yoshiki-Gravelsins and Toguri, 1993; Kress, 2007; Mungall, 2007).

\section{EXPERIMENTAL METHODS}

The experimental set-up used was the same for all experiments. Each experimental charge consisted of $\sim 1 \mathrm{~g}$ of troi- lite $(\mathrm{Fe} / \mathrm{S}$ atomic $=1)$ powder of $99.99 \%$ purity placed inside an open capsule, $1 \mathrm{~cm}$ in diameter and $2 \mathrm{~cm}$ in height, made from pure $\mathrm{SiO}_{2}$ glass. The crucibles were suspended in a vertical muffle tube furnace equipped for gas mixing, in which both $f \mathrm{O}_{2}$ and $f \mathrm{~S}_{2}$ were controlled independently using $\mathrm{CO}_{2}-\mathrm{CO}-\mathrm{SO}_{2}$ gas mixtures. The gas flows were measured using Tylan F2800 mass flow controllers. Two controllers were available for each gas, with ranges between 10 and 200 SCCM (standard cubic centimetres per minute) for $\mathrm{CO}$ and $\mathrm{CO}_{2}$ and $10-100 \mathrm{SCCM}$ for $\mathrm{SO}_{2}$. The $f \mathrm{O}_{2}$ and $f \mathrm{~S}_{2}$ for each run were calculated using the thermodynamic data for gas species in the NIST-JANAF tables (Chase, 1998) according to O'Neill and Mavrogenes (2002). The gas flows used for our experimental runs can be found as an Electronic Annex EA1 to this manuscript. The temperature was held constant to $\pm 5^{\circ}$ for the duration of each run using a central $\mathrm{Pt}-\mathrm{Rh}$ thermocouple external to the muffle tube. The achievement of equilibrium was subsequently checked by analysing sulphides run for different times, which showed that at least $24 \mathrm{~h}$ are needed for the matte to equilibrate with the gas mixture in the furnace. Experimental charges were left in the furnace for $96 \mathrm{~h}$, at $1200{ }^{\circ} \mathrm{C}, 72 \mathrm{~h}$, at $1300^{\circ} \mathrm{C}$, and $24 \mathrm{~h}$, at $1400^{\circ} \mathrm{C}$, to ensure equilibrium between the gas mixture and the matte. At the end of each run the charges were quenched by dropping them into a beaker of cold water. The experimental products were then recovered, mounted in epoxy resin and polished for analysis.

\section{ANALYTICAL METHODS}

\subsection{Major elements: wavelength dispersive spectroscopy (WDS)}

Both sulphide and alloy phases were analysed using the CAMECA SX100 Electron Microprobe (EMP), in wavelength dispersive mode (WDS), at $15 \mathrm{kV}$ acceleration voltage and $20 \mathrm{nA}$ beam current. given the heterogeneity at the $\mu \mathrm{m}$ scale of the experimental run products in this study, sulphides were analysed for $\mathrm{Fe}, \mathrm{S}, \mathrm{Ni}, \mathrm{Cr}, \mathrm{Cu}$ and $\mathrm{Si}$ (to track crucible contamination) in area scans in $300 \mu \mathrm{m} \times 300 \mu \mathrm{m}$ grids with a $10 \mu \mathrm{m}$ beam. Standard calibrations were carried out using pure troilite for $\mathrm{Fe}$ and $\mathrm{S}$, $\mathrm{NiS}$ for $\mathrm{Ni}$, chalcopyrite for $\mathrm{Cu}, \mathrm{Cr}-$ metal for $\mathrm{Cr}$, and $\mathrm{SiO}_{2}$ for $\mathrm{Si}$.

\subsection{Analysing oxygen}

Despite being the most abundant element in the Earth, O has been one of the most difficult elements for geochemists and material scientists to analyse accurately, but modern electron microprobe instrumentation makes the precise analysis of $\mathrm{O}$ possible. Several previous studies have used the EMP to measure $\mathrm{O}$ in sulphides (e.g. Kress, 1997; Gaetani and Grove, 1999; Brenan and Caciagli, 2000; Larocque et al., 2000; Nagamori and Yazawa, 2001; Rose and Brenan, 2001; Andrews and Brenan, 2002; Brenan and Rose, 2002; Mungall et al., 2005; Kress, 2007), however, the lack of suitable standards for $O$ in sulphides is an issue (McGuire et al., 1992), 
and the accuracy of many measurements is also hard to evaluate because detailed information on $\mathrm{O}$ calibrations and the method used to measure background in sulphides are not given.

In this study, calibrations for $\mathrm{O}$ were initially performed using the CAMECA SX100 EMP with the synthetic monolayer crystals PC0 $(2 d=45 \AA)$ and PC2 $(2 d=100 \AA)$. Peak and background positions, as well as background geometry, were found to vary from standard to standard, and between standards and the unknown (Fig. 2). The variations in the $\mathrm{O} \mathrm{K} \alpha$ peak position have been described previously by Liang (1991), who showed that the O K $\alpha$ peak undergoes a significant shift (0.024-0.043 $\AA$ ) for different O standards, using a W-Si multilayer pseudocrystal $(2 d=59.8 \AA$ ). Liang (1991) observed that "in the direct determination of oxygen, a peak count reduction could occur as a result of this peak shift effect if unsuitable oxygen standards are used". In this study, early attempts at analysis of nominally $\mathrm{O}$-free samples, using $\mathrm{O}$ calibrations done on different standards, yielded either negative concentrations or "phantom" amounts of $\mathrm{O}$ in the sulphide, confirming the point made by Liang (1991). Moreover, analysis of O with a PC2 crystal has the additional complication of several interferences associated with high-order Fe L lines, which makes analysis
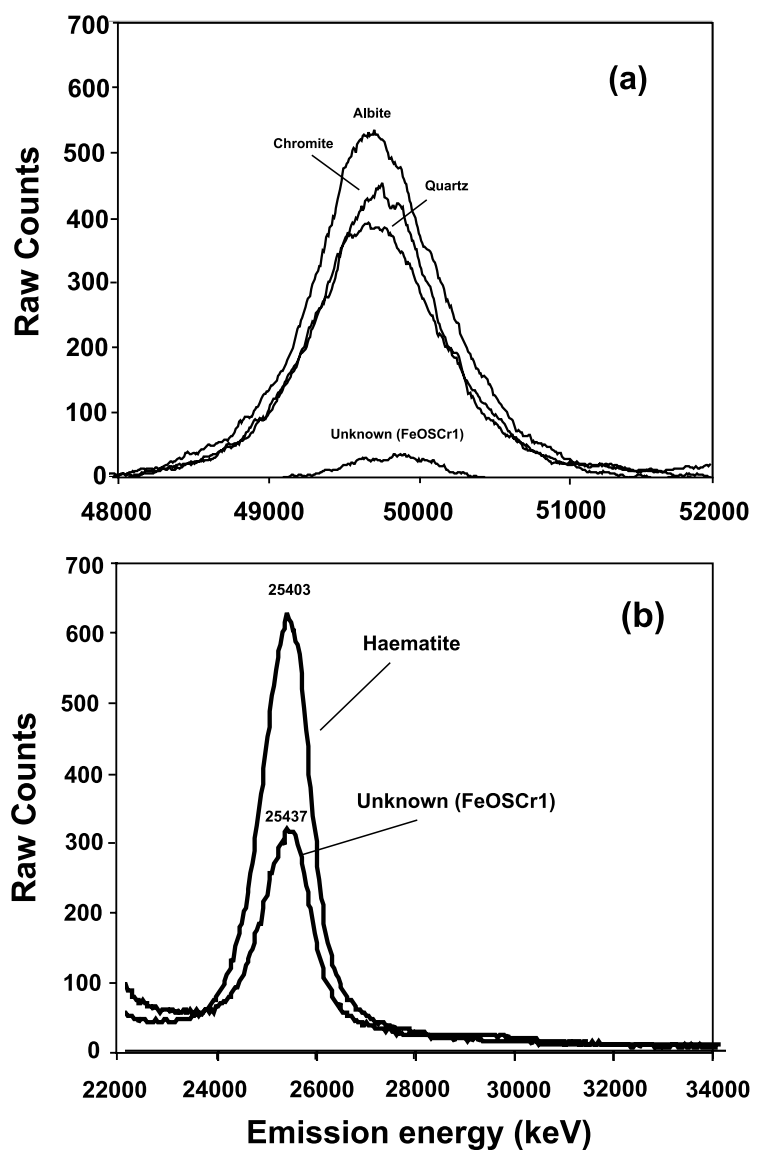

Fig. 2. Examples of variations in the peak (a) and background (b) positions of $\mathrm{O}$ for different standards and our unknowns given by WDS scans of the $\mathrm{O} \mathrm{K} \alpha \mathrm{X}$-ray peak using the PC0 and the PC2 pseudocrystal, respectively. in Fe sulphides particularly difficult. An additional problem of using WDS for $\mathrm{O}$ analysis is that both the minimum beam width (above $1 \mu \mathrm{m}$ ) and associated interaction volumes (over $5 \mu \mathrm{m}$ ) are too large for analysis of some of the oxygen-bearing quench phases. Calibrations for $\mathrm{O}$ were conducted on rutile $\left(\mathrm{TiO}_{2}\right)$, chromite and quartz using the PC0 monolayer pseudocrystal. Because of the peak shift effect, and the fact that the background in the low energy part of the WDS spectrum is curved, calibrations were conducted in peak area mode rather than by the usual peak and background measurements. Given the heterogeneity at the $\mu \mathrm{m}$ scale characteristic of the samples in this study, analysis was initially conducted using an unfocused beam of $10 \mu \mathrm{m}$ width. However, this approach failed to produce reliable results, with the oxygen count rate changing by over a factor of two over a period of hours, probably due to carbon build-up on the surface of the samples. An alternate approach was therefore used in which the sample stage was moved in a boustrophedonic pattern over a distance of $\pm 20 \mu \mathrm{m}$ from the central position, while the beam was kept focused with a constant width of $1 \mu \mathrm{m}$; this method was implemented using a stage-control program WANDER written by Ashley Norris. Beam conditions were set at $15 \mathrm{kV}$ acceleration voltage and $20 \mathrm{nA}$ beam current. Counting times for $\mathrm{O}$ peaks was set at $180 \mathrm{~s}$ and $\mathrm{O}$ detection limits were $\pm 0.1 \mathrm{wt} \%$.

Oxygen was also analysed using a JEOL 6400 scanning electron microscope, in EDS mode. The disadvantages of analysis by EDS are: (i) low peak resolution, (ii) possible peak overlaps, and (iii) lower detection limits when compared to WDS quantitative analysis in peak area mode. The advantages of EDS analyses is that it provides rapid analysis of very small domains in samples, due to its smaller beam width (as low as $0.01 \mu \mathrm{m}$ ), and smaller interaction volume. Beam conditions were set at $15 \mathrm{kV}$ acceleration voltage and $1 \mathrm{nA}$ beam current. Standard calibrations for $\mathrm{O}$ were carried out using albite. Only data that yielded totals between 98.5 and $101.5 \mathrm{wt} \%$ were used. About $5 \%$ of analysis were rejected on this basis, and the poor results are attributed to bad polishing of the sample or surface charging effects. Standard calibrations were performed immediately prior to the sample analysis. In addition, freshly polished oxygen-free troilite standards were analysed to measure "blank" oxygen levels. It was found that these nominally oxygen-free standards returned oxygen concentrations of $0.81 \pm 0.09 \mathrm{wt} \%$, due to errors in assigning the baseline under the oxygen $\mathrm{K} \alpha$ peak in Fe-rich samples resulting from the close proximity of the $\mathrm{Fe} \mathrm{L} \alpha$ lines. This value was therefore subtracted from all nominal values of $\mathrm{O}$ concentrations. X-ray maps confirmed the presence of oxygen at low concentrations along the grain boundaries of sulphides, even in samples run at the lowest $f \mathrm{O}_{2}$ (Fig. 3). Image analysis of the X-ray maps, using the ImageJ software, was performed independently of the EDS analysis and showed good agreement with the quantitative analysis. A comparison between data obtained from WDS with background corrected EDS data for the same samples showed good agreement with an $R^{2}=0.97$ (Fig. 4). 


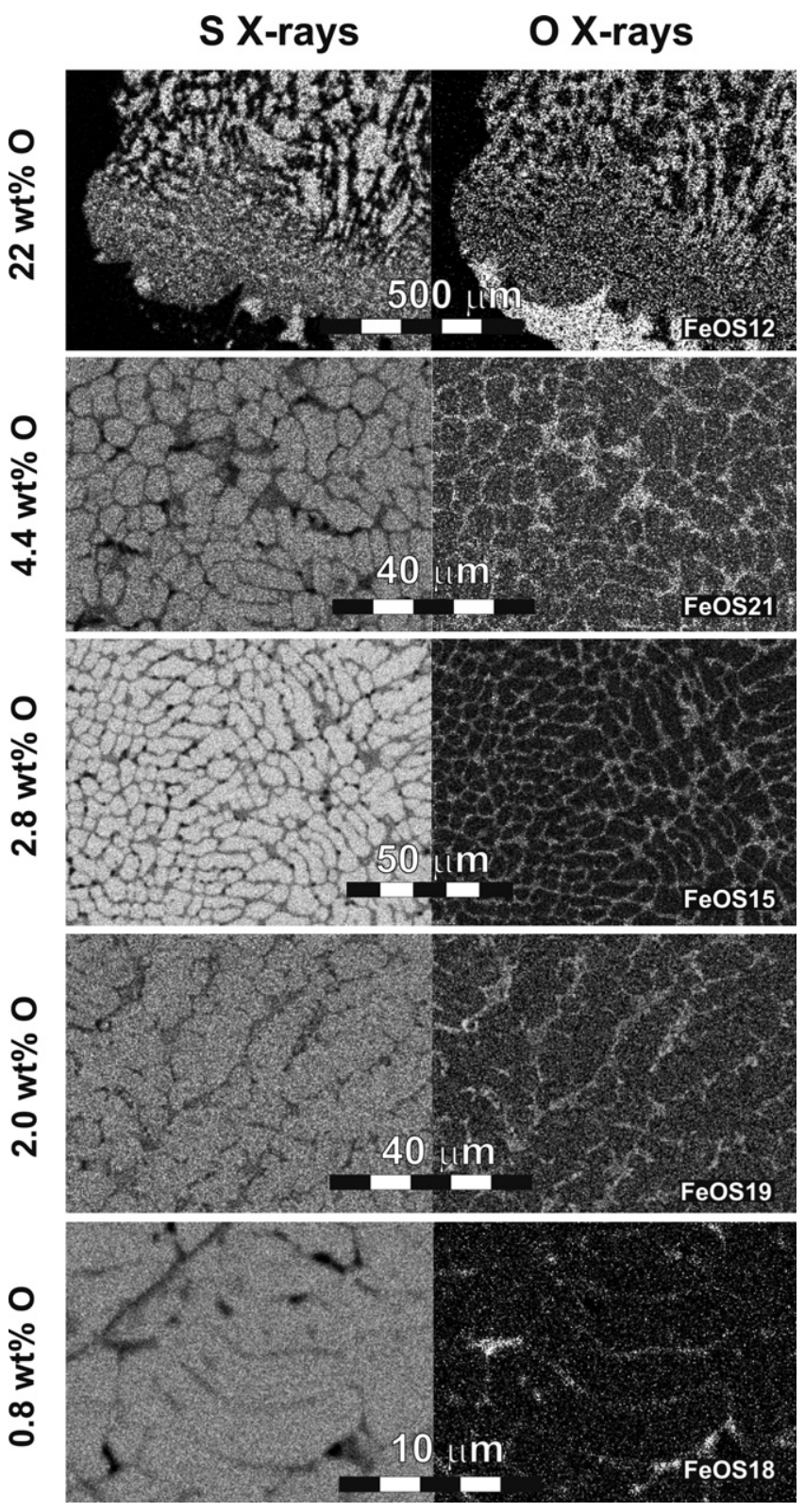

Fig. 3. X-ray maps for $\mathrm{O}$ and $\mathrm{S}$ for samples with different oxygen concentrations. It was found that even at very low oxygen values, oxygen was present in interstitial grain boundaries, where $\mathrm{S}$ was depleted. Discrete O-rich phase featured in the bottom of the $22 \mathrm{wt} \% \mathrm{OX}$-ray map, is the crucible material and was not taken into account in the average $\mathrm{O}$ content of that particular run.

\subsection{X-ray diffraction (XRD) and transmission electron microscope (TEM)}

\subsubsection{XRD-X-ray diffraction}

Nominally metal-free samples of sulphide were ground in acetone, and the resulting powder was mounted for powder X-ray diffraction (XRD). XRD diffraction patterns were determined using a Siemens D-5005 diffractometer (scintillation counter and $\mathrm{Co} \mathrm{K} \alpha$ radiation). Sample mixtures were sedimented onto a "zero background" quartz plate that was rotated while intensity data were collected from $10^{\circ}$ to $90^{\circ} 2 \theta$ in $0.01^{\circ}$ increments taking $9 \mathrm{~s}$ per step.
Rietveld refinement was carried out using the program DBWS-9807 (Young et al., 1995). $R_{\text {Bragg values were } \sim 3}$ for mss and $\sim 2$ for wüstite $\left(\mathrm{Fe}_{1-\mathrm{x}} \mathrm{O}\right)$.

\subsubsection{TEM-transmission electron microscopy}

Samples were prepared by crushing in acetone, drying and transferring onto a TEM copper specimen grid precoated for lattice fringe resolution work with a perforated carbon thin film. TEM imaging, diffraction and analysis was carried out at $300 \mathrm{kV}$ using a Phillips CM300T with a LaB6 filament, and a Gatan 794 multi-scan CCD camera. The chemical composition of powdered samples was qualitatively checked 


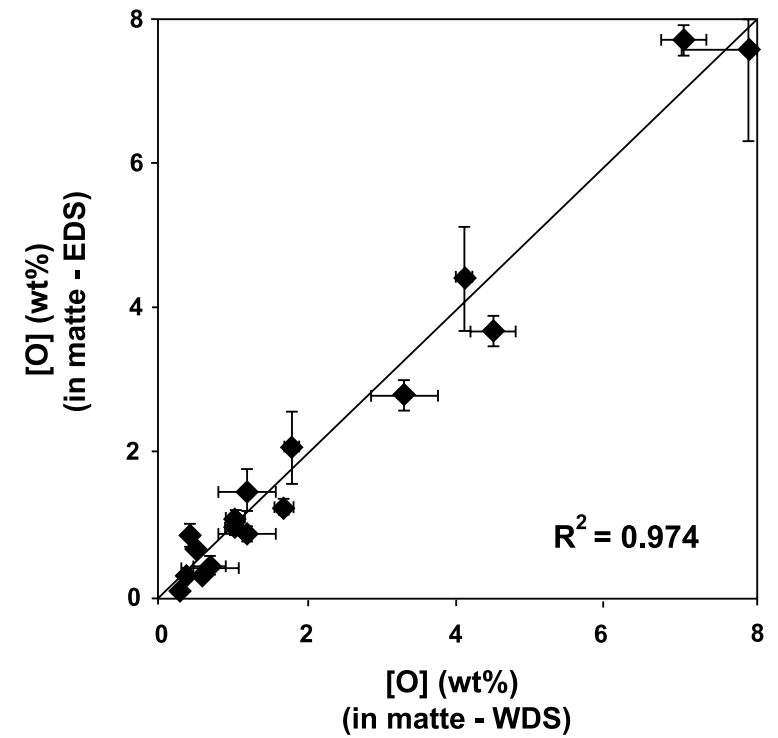

Fig. 4. Comparison of $\mathrm{O}$ concentrations in matte obtained in WDS and EDS modes.

using an X-ray energy dispersive spectrometer (XEDS), fitted with an EDAX super-ultra-thin-window $\mathrm{Si}(\mathrm{Li})$ X-ray detector.

\section{RESULTS}

Experimental conditions and compositions are listed in Table 1. Fig. 5 is a plot of $\mathrm{O}$ concentrations in the matte as a function of $f \mathrm{O}_{2}$, which increase with increasing $f \mathrm{O}_{2}$ to a maximum of $\sim 7 \mathrm{wt} \%(\sim 18$ at $\% \mathrm{O})$ for run FeOS2 at a $\log f \mathrm{~S}_{2}=-3.0$ and $\log f \mathrm{O}_{2}=-10.3$. At higher $f \mathrm{O}_{2}$ the matte reacts extensively with the "quartz" crucible leading to the formation of a mixture of silicate glass, magnetite and sulphide droplets in the quench (runs FeOS1 and FeOS11). Because the experimental charges in runs FeOS1 and FeOS11 reacted extensively with the silica crucible, we have not used these data. Temperature does not have a significant effect on the solubility of $\mathrm{O}$ in matte over the range of temperatures studied (1200-1400 $\left.{ }^{\circ} \mathrm{C}\right)$.

Fig. 6 are plots of the concentration of $\mathrm{O}$ in the matte as a function of $f \mathrm{~S}_{2}$. The $\mathrm{O}$ content in the matte is shown to be inversely correlated with $f \mathrm{~S}_{2}$ for all temperatures. The data for $1250{ }^{\circ} \mathrm{C}$ of Kress (1997) has higher O concentrations in the matte when compared to our data for $1200{ }^{\circ} \mathrm{C}$, because these runs were carried out at a higher $f \mathrm{O}_{2}\left(\log f \mathrm{O}_{2} \sim-8.5\right.$ for $\left.1250^{\circ} \mathrm{C}\right)$. Fig. 7 is a plot of excess anions, $\mathrm{O}^{2-}$ and $\mathrm{S}^{2-}$, over $\mathrm{Fe}$ in the matte as a function of $\mathrm{O} /(\mathrm{O}+\mathrm{S})$, which is proportional to $f \mathrm{O}_{2}$. Assuming that both $\mathrm{O}$ and $\mathrm{S}$ are in their $2-$ state, a positive $(\mathrm{O}+\mathrm{S})-\mathrm{Fe}$ reflects the presence of $\mathrm{Fe}^{3+}$ in the matte, whereas a negative $(\mathrm{O}+\mathrm{S})-\mathrm{Fe}$ reflects the presence of $\mathrm{Fe}^{0}$ in the matte. The $\mathrm{Fe}^{3+}$ content of the matte increases with increasing $\mathrm{O} /(\mathrm{O}+\mathrm{S})$ at all temperatures, in agreement with the data in Kress (1997). Negative $(\mathrm{O}+\mathrm{S})-$ $\mathrm{Fe}$, indicating $\mathrm{Fe}^{0}$ in the matte, occurs at $\mathrm{O} /$ $(\mathrm{O}+\mathrm{S})<0.1$, which is supported by the presence of rare $\mathrm{Fe}$ nuggets in the quench at lower $f \mathrm{O}_{2}$ (e.g. run $\mathrm{FeOS} 13$ ).
Figs. 8 and 9 are plots of the mole fraction of Fe, S and $\mathrm{O}$ as a function of $f \mathrm{O}_{2}$ and $f \mathrm{~S}_{2}$, respectively, for the temperatures of $1200{ }^{\circ} \mathrm{C}, 1250{ }^{\circ} \mathrm{C}$ (Kress, 1997) and $1300^{\circ} \mathrm{C}$. As found in previous work (e.g. Kress, 1997, and references therein), Fe content of the matte is independent of temperature, $f \mathrm{O}_{2}$ and $f \mathrm{~S}_{2}$ over the range of experimental conditions studied (Figs. 8 and 9). On the other hand, $\mathrm{O}$ substitutes for $\mathrm{S}$ in the matte at increasing $\mathrm{fO}_{2}$ and decreasing $f \mathrm{~S}_{2}$, as shown by their negative correlation in Figs. 8 and 9.

Run FeOSCrl was saturated with $\mathrm{Cr}$ metal and run at $1200^{\circ} \mathrm{C}$ and at a $\log f \mathrm{O}_{2}=-10.5(\sim \mathrm{QFM}-2)$. The aim of run $\mathrm{FeOSCr} 1$ was to measure the solubility of $\mathrm{Cr}$ in the matte and in the quenched phases. Subhedral to euhedral chromite crystals formed (Fig. 10), indicating that they crystallised before quenching took place. The mss did not contain detectable $\mathrm{Cr}$, whereas the FeSO phase had $\sim 0.3 \mathrm{wt} \% \mathrm{Cr}$. FeO was not analysed for its $\mathrm{Cr}$ content because it is only detectable at the TEM scale $(\sim 0.5 \mu \mathrm{m})$. This result suggests that in $\mathrm{Cr}$-undersaturated natural mattes, most, if not all of the $\mathrm{Cr}$ would be concentrated with the FeSO species, albeit in small amounts.

\subsection{Identification of stoichiometric FeSO in the matte}

The results presented here are similar to those of Kress (1997) who used a rapid quench device to provide a relatively homogeneous sample after quenching, with the absence of quench crystals at the micron scale, which clearly facilitates subsequent bulk analysis, but at the expense of being able to easily identify the quench products. Here, electron backscatter images of relatively O-rich samples (Fig. 11A) show the presence of two phases, mss grains devoid of $\mathrm{O}$ content, and an O-rich phase in interstitial spaces (Fig. 11B). X-ray mapping of $\mathrm{O}$ and $\mathrm{S}$ in run FeOS2 (Fig. 3) shows that $\mathrm{O}$ is concentrated in the interstitial spaces between sulphide grains while $\mathrm{S}$ is concentrated in $\mathrm{O}$ poor areas. Numerous electron microprobe analyses of the $\mathrm{O}$ rich phase (approximately 5 per run) in Fig. 11B showed that it consistently had the stoichiometry of $\mathrm{Fe}_{0,99} \mathrm{~S}_{1,00} \mathrm{O}_{1,01}$. $\mathrm{X}$-ray diffraction of one of the more O-rich runs (run FeOS2) identified only three crystalline phases; mss, wüstite and cristobalite (recrystallised fragments of the wall of the crucible), which raised the possibility that the interstitial O-rich phase is a quenched glass with FeSO stoichiometry. TEM analysis of run FeOS2 (Fig. 12) confirmed the presence of a glass (Fig. 12C) with a FeSO stoichiometric composition, suggesting that FeSO existed in the matte as constituent species, which then quenched to a glass, coating grains of mss. It may be possible that glassy inclusions might exist in the mss grains. However, these inclusions were not identified in BSE images.

\subsection{Activity of $\mathrm{FeO}$ in the $\mathrm{Fe}-\mathrm{S}-\mathrm{O}$ system}

Shima and Naldrett (1975) used the $a_{\mathrm{Fe}}$ in binary Fe-S liquids at $1200^{\circ} \mathrm{C}$ (Nagamori and Kameda, 1965), and $1120^{\circ} \mathrm{C}$ and $1400{ }^{\circ} \mathrm{C}$ (Bog and Rosenqvist, 1958), to calculate $a_{\mathrm{FeO}}$ from Darken and Gurry's (1946) data for the standard free energy for the reaction: 
Table 1

Experimental conditions and major element concentrations

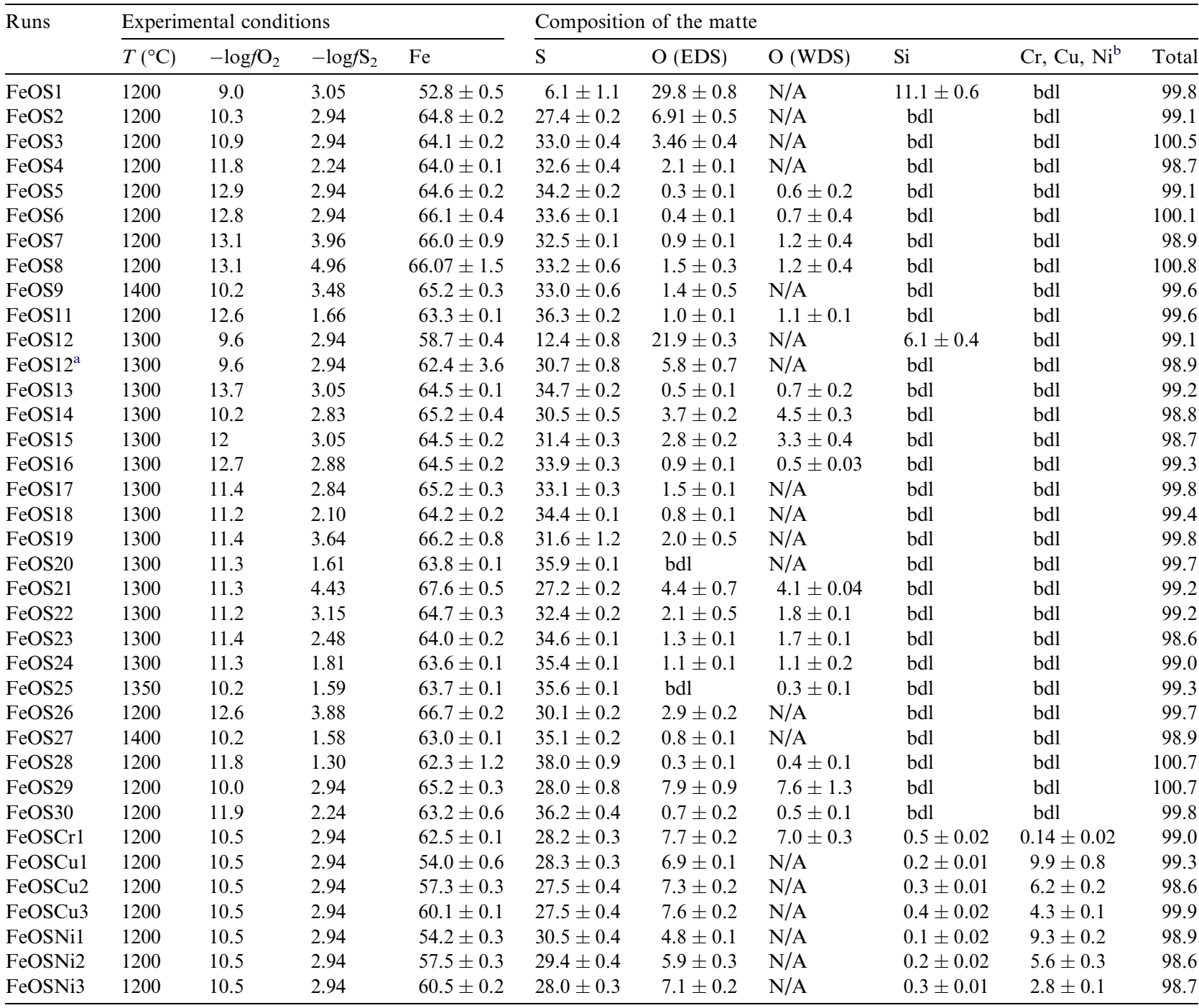

a Sulphide droplets.

b This column represents $\mathrm{Cr}$ content in run FeOSCr1, $\mathrm{Cu}$ content in runs FeOS Cul-3 and Ni content in runs FeOSNil-3.

$\mathrm{Fe}+1 / 2 \mathrm{O}_{2} \leftrightarrow \mathrm{FeO}$

Following Shima and Naldrett (1975), $-\log f \mathrm{O}_{2}$ and $-\log f \mathrm{~S}_{2}$ have been contoured for a part of the Fe-S-O ternary phase diagram using the matte compositions determined in this study for $f \mathrm{O}_{2}$ and $f \mathrm{~S}_{2}$ at temperatures of $1200^{\circ} \mathrm{C}$ and $1300^{\circ} \mathrm{C}$ (Fig. 13A and B). Superimposed on Fig. $13 \mathrm{~A}$ and $\mathrm{B}$, are the $a_{\mathrm{FeO}}$ curves calculated for $1200{ }^{\circ} \mathrm{C}$ by Shima and Naldrett (1975).

Naldrett (1969) pointed out that by controlling $f \mathrm{O}_{2}$ and $f \mathrm{~S}_{2}$ for a liquid in the $\mathrm{Fe}-\mathrm{S}-\mathrm{O}$ system at any given temperature and pressure, one also controls the composition, and from reaction 2 , the $a_{\mathrm{FeO}}$ of the matte. When a matte segregates from a given silicate melt, the condition of thermodynamic equilibrium requires the $a_{\mathrm{FeO}}$ in both the matte and silicate melt to be the same. As in Shima and Naldrett (1975), the $a_{\mathrm{FeO}}$ will decrease with increasing $f \mathrm{~S}_{2}$, so that the lower the $a_{\mathrm{FeO}}$ of the silicate melt, the higher the $f \mathrm{~S}_{2}$ needs to be for the segregation of a $\mathrm{Fe}-\mathrm{S}-\mathrm{O}$ matte to occur. For example, if a silicate melt at $1200{ }^{\circ} \mathrm{C}$ and with a $\log f \mathrm{O}_{2}$ of -10 has an $a_{\mathrm{FeO}}$ of 0.1 , the minimum $\log / \mathrm{S}_{2}$ necessary to trigger segregation of a Fe-S-O matte, is $\sim-2.2$, which is in close agreement to the determined value of -2.6 determined by Shima and Naldrett (1975) under the same conditions. Despite the similarity between this study and Shima and Naldrett (1975), the $f S_{2}$ contours are slightly different in both studies. The most likely explanation is that different methods were used to analyse O: EMP in this study versus O calculated by difference in Shima and Naldrett (1975).

The above discussion assumes that $\mathrm{Fe}$ is the only cation to enter the sulphide-rich matte. The presence of $\mathrm{Ni}$ and $\mathrm{Cu}$ triggers matte segregation at a different $f S_{2}$ than in the pure $\mathrm{Fe}-\mathrm{S}-\mathrm{O}$ system, since these elements are likely to influence the $a_{\mathrm{FeO}}$ of the system. 


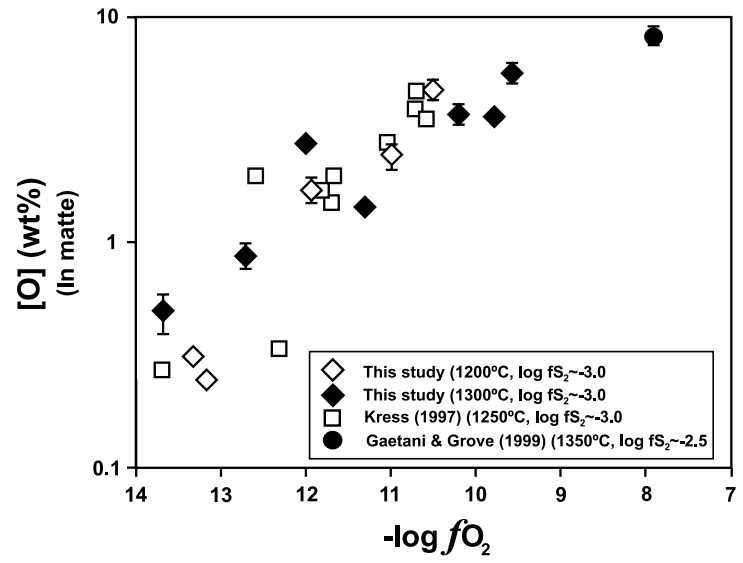

Fig. 5. O concentrations in matte as a function of oxygen fugacity at $1200{ }^{\circ} \mathrm{C}, 1250{ }^{\circ} \mathrm{C}$ (Kress, 1997), $1300{ }^{\circ} \mathrm{C}$ and $1350{ }^{\circ} \mathrm{C}$ (Gaetani and Grove, 1999). Datasets for different temperatures show good agreement between them, indicating that temperature has a negligible effect to the solubility of $\mathrm{O}$ in the matte.

\subsection{The solubility of $\mathrm{O}$ in a $\mathrm{S}$-rich $\mathrm{Fe}-\mathrm{S}-\mathrm{O}$ matte as a function of $f \mathrm{~S}_{2}, f \mathrm{O}_{2}$ and $T$}

Kress (2000) developed an algorithm based on an associated solution model for sulphide liquids in the system $\mathrm{Fe}-\mathrm{S}-\mathrm{O}$. The model is quite computationally complex and difficult to implement. Here we present a simple parameterisation of the experimental results that allows the solubility of $\mathrm{O}$ in sulphide-rich mattes to be calculated as a function of $f \mathrm{O}_{2}, f \mathrm{~S}_{2}$ and temperature. The parameterisation was obtained by least-squares fitting to a number of datasets from the literature, as listed in Table 2. Several criteria were used to decide which data were reliable. Firstly, only data that was obtained through experimental studies carried out at $1 \mathrm{~atm}$ in furnaces equipped for accurate simultaneous control of $\mathrm{fO}_{2}$ and $f \mathrm{~S}_{2}$ by gas mixing were considered. Secondly, data from studies where no analytical methods for analysis of $\mathrm{O}$ are described were rejected. Thirdly, any obvious outliers from groups of data were also excluded. The rationale for the exclusion of obvious outliers, hinges on the fact that small disruptions in the $\mathrm{SO}_{2}, \mathrm{CO}$ and $\mathrm{CO}_{2}$ gas flows, can change the stoichiometry of sulphides considerably resulting in obvious outliers in a composition versus $f \mathrm{O}_{2}$ or $f \mathrm{~S}_{2}$ plot. Therefore, by default, outliers that represent more than two standard deviations from the mean are rejected. Finally, data that displayed an obvious analytical bias, i.e. $\mathrm{H}$ extraction versus EMP, were also excluded. An example of analytical bias is shown by the $\mathrm{O}$ solubility data in mattes, from Nagamori and Kameda (1965), which systematically displays higher concentrations of $\mathrm{O}$ for the same $f \mathrm{O}_{2} / f \mathrm{~S}_{2}$ when compared to other data obtained by EMP (Fig. 14). A summary of the data sources, the range of conditions investigated, the analytical method used and the number of data rejected for each study are given in Table 2 .

Fig. 15 shows the range of compositions (a) and conditions (b) covered by each of the studies considered. The range of $f \mathrm{~S}_{2}, f \mathrm{O}_{2}$ and $T$ covered by each one of the stud-

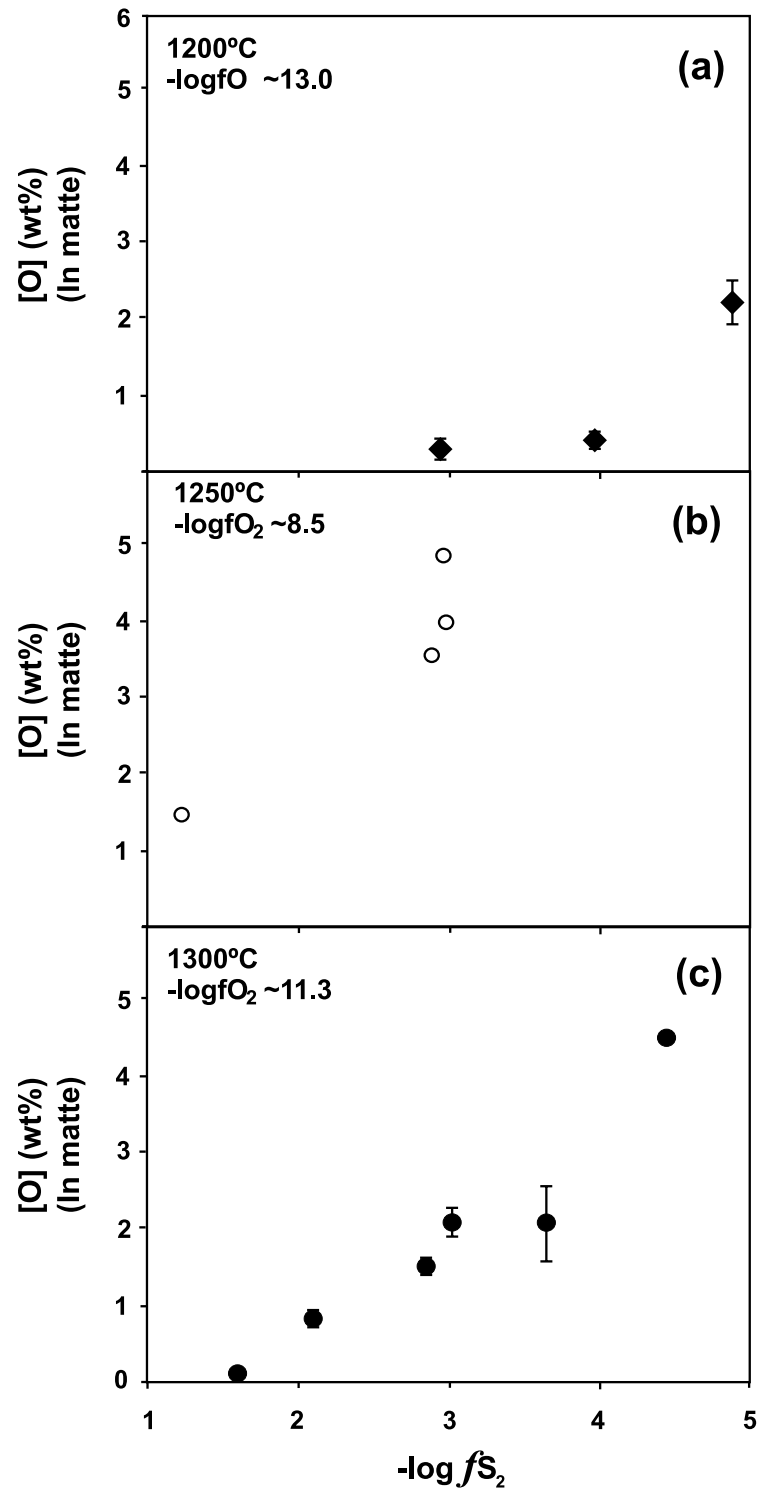

Fig. 6. Solubility of $\mathrm{O}$ in matte as a function of $f \mathrm{~S}_{2}$ at (a) 1200 , (b) 1250 (Kress, 1997) and (c) $1300^{\circ} \mathrm{C}$. O solubility in the matte decreases with increasing $f \mathrm{~S}_{2}$ for all temperatures and values of $f \mathrm{O}_{2}$.

ies described in Table 2 is limited but by combining all of the studies a large range of conditions is obtained, which is pertinent to the crust and the upper mantle (Fig. 15A). In terms of the composition of the matte, all of the studies, regardless of temperature have a $\mathrm{Fe} /(\mathrm{S}+\mathrm{O})$ molar ratio very close to one (Fig. 15B), characteristic of sulphide-rich mattes of the upper mantle. Studies of S-containing liquid metals with $\mathrm{Fe} /(\mathrm{S}+\mathrm{O}) \gg 1$ (e.g. Jana and Walker, 1997; Fleet et al., 1999; Lazar et al., 2004) were not considered.

The filtered data were fit to the following equation:

$\ln [\mathrm{O}]_{\text {matte }}=A+\frac{B}{T(K)}+C \ln f \mathrm{O}_{2}-D \ln f \mathrm{~S}_{2}$

where $A, B, C$ and $D$ and empirical fitting constants. The result of this fit is: 


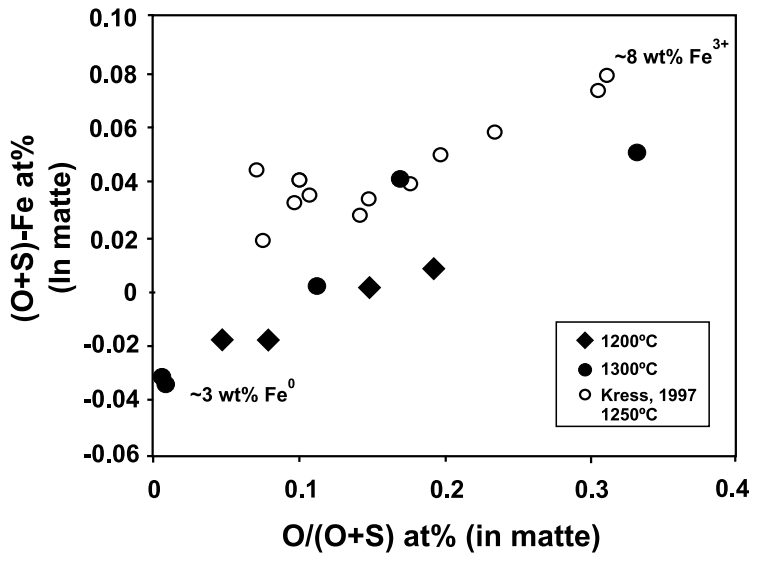

Fig. 7. Excess anions over $\mathrm{Fe}((\mathrm{O}+\mathrm{S})-\mathrm{Fe})$ as a function of $\mathrm{O} /(\mathrm{O}+\mathrm{S})$. Assuming that $\mathrm{S}$ and $\mathrm{O}$ have valences of $2-$, excess of anions over Fe reflects the presence of ferric iron in the matte with increasing $\mathrm{O} /(\mathrm{O}+\mathrm{S})$, whereas at low $\mathrm{O} /(\mathrm{O}+\mathrm{S})$ negative $(\mathrm{O}+\mathrm{S})-$ $\mathrm{Fe})$ reflect the presence of $\mathrm{Fe}^{0}$.

$\ln [\mathrm{O}]_{\text {matte }}=-2.99+\frac{17550}{T(K)}+0.334 \ln f \mathrm{O}_{2}-0.149 \ln f \mathrm{~S}_{2}$

with $\chi_{v}^{2}=2.55$.

Some of the studies quoted in Table 2 did not quote uncertainties, in which case we assumed $\sigma \log _{10} f \mathrm{O}_{2}$ and $\sigma \log _{10} f \mathrm{~S}_{2}=0.1 ; \sigma[\mathrm{O}]_{\text {matte }}=0.1+0.1[\mathrm{O}]_{\text {matte }}$; if $[\mathrm{O}]_{\text {matte }}$ was reported as zero we assumed it to be $0.1 \pm 0.1$. Note that our empirical parameterisation returns coefficients $C$ and $D$ that are different from the values expected thermodynamically from the stoichiometry of reaction 1 , namely +0.5 and -0.5 , respectively. This discrepancy with thermodynamic behaviour has been found previously (e.g. Nagamori and Kameda, 1965; Blatov et al., 1997; Kress, 1997; Nagamori and Yazawa, 2001).

Fig. 16, is a plot of the $\mathrm{O}$ concentrations measured in the matte against the $\mathrm{O}$ concentrations in the matte as calculated through Eq. (4). The agreement between measured and calculated $\mathrm{O}$ contents of the matte is excellent, except at lower concentrations of $\mathrm{O}$ where calculated concentrations tend to be slightly higher than the measured ones. This is plausibly the result of poor data quality at very low $\mathrm{O}$ concentrations due to difficulties in measuring $\mathrm{O}$ at very low concentrations by EMP. Fig. 17 is a plot of the difference between measured and calculated $\mathrm{O}$ concentrations in the matte as a function of $f \mathrm{O}_{2}$, here shown as relative to $\mathrm{QFM}$, and for different intervals of $f \mathrm{~S}_{2}$. The aim of this diagram was to test whether there was any prevalence of outliers for a given range of conditions. Outliers do not show any preference to particular intervals of $f \mathrm{O}_{2}$ and $f \mathrm{~S}_{2}$, and display a random distribution.

Fig. 18 is a comparison between the mole fractions of $\mathrm{S}$ in the matte as a function of $f \mathrm{~S}_{2}(\mathrm{a})$, and of $\mathrm{O}$ in the matte as a function of $f_{2}(\mathrm{~b})$, with the predicted mole fractions for both $\mathrm{O}$ and $\mathrm{S}$ based on a thermodynamic model of the system $\mathrm{Fe}-\mathrm{S}-\mathrm{O}$ by Kress (2000), and the empirical fit by Eq. (4). The agreement between the Kress model and our empirical fit is striking with regard to $\mathrm{O}$ concentrations

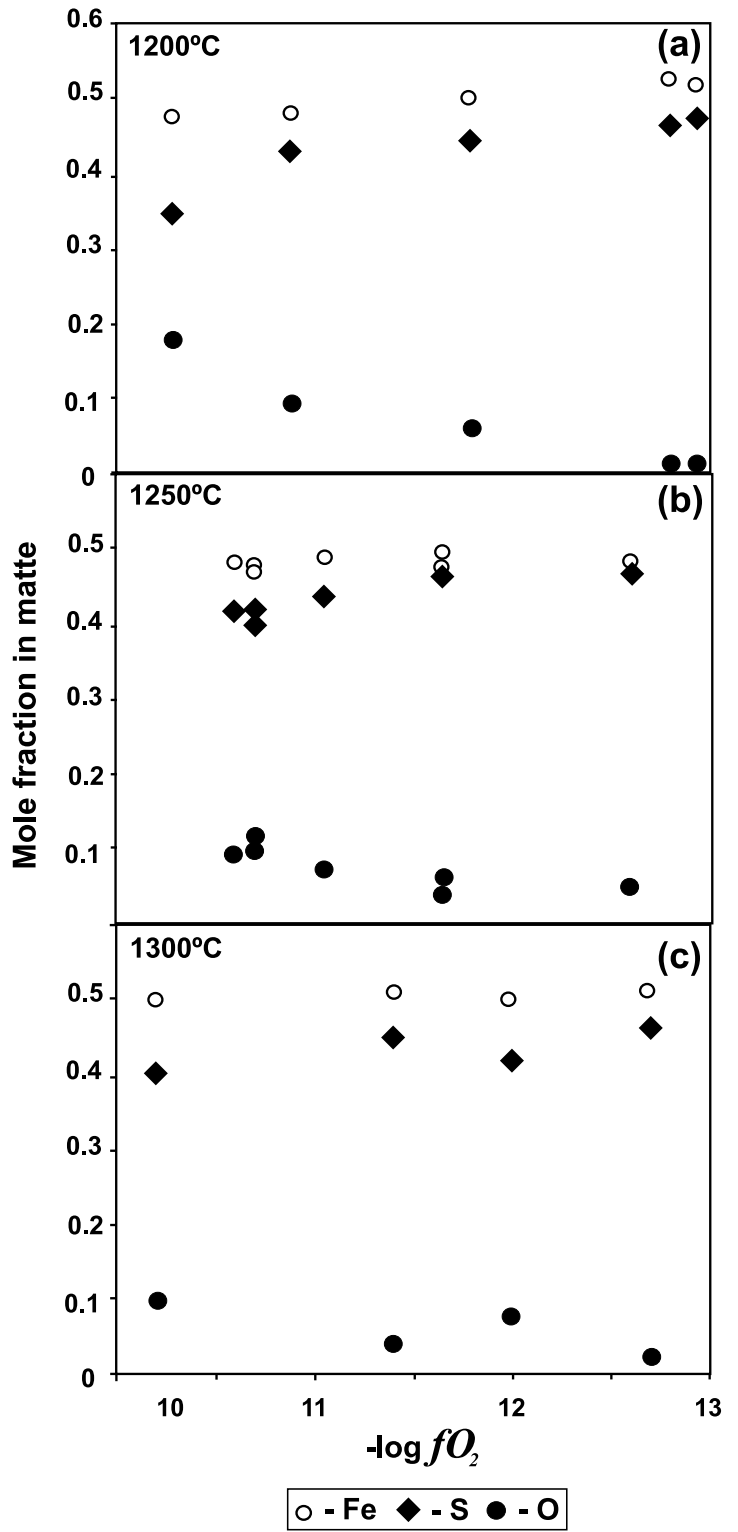

Fig. 8. Mole fraction of $\mathrm{O}, \mathrm{S}$ and $\mathrm{Fe}$ as a function of $f \mathrm{O}_{2}$ at constant $f \mathrm{~S}_{2}\left(10^{-3}\right.$ bar) for the temperatures of (a) 1200 , (b) 1250 (Kress, 1997) and (c) $1300{ }^{\circ} \mathrm{C}$.

in the matte as a function of $f \mathrm{O}_{2}$. However, the Kress model and the empirical fit do not agree with regard to how the molar fraction of $\mathrm{S}$ changes with $f \mathrm{~S}_{2}$, especially at $\log f \mathrm{~S}_{2}$ higher than -1.5 and lower than -4.5 . This discrepancy may be explained by the fact that our empirical fit is constrained by a larger dataset $(n \sim 300)$ than that used by Kress (2000).

\subsection{The effect of $\mathrm{Cu}$ and $\mathrm{Ni}$ on the solubility of $\mathrm{O}$ in matte}

As discussed previously the relevance of the Fe-S-O system to natural systems hinges on our knowledge of the effects of other cations, such as $\mathrm{Cu}$ and $\mathrm{Ni}$. Several experiments were carried out to investigate the effect of composition on the solubility of oxygen in matte. Temperature 


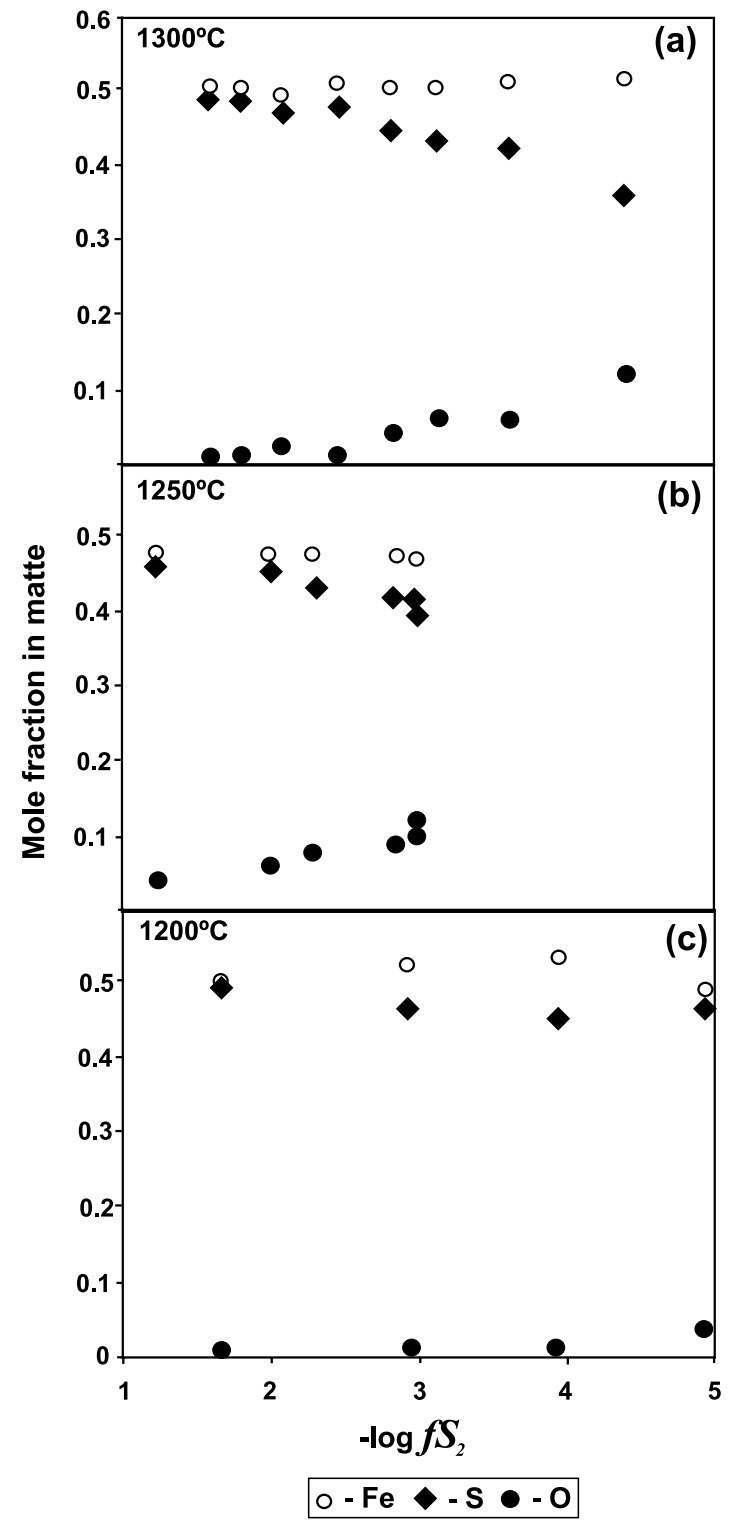

Fig. 9. Mole fraction of $\mathrm{O}, \mathrm{S}$ and $\mathrm{Fe}$ as a function of $f \mathrm{~S}_{2}$ at constant $f \mathrm{O}_{2}\left(\sim 10^{-11.3}\right.$ bar $)$ for the temperatures of (a) 1200 , (b) 1250 (Kress, 1997) and (c) $1300^{\circ} \mathrm{C}$.

and $\log f \mathrm{O}_{2}$ were kept at a constant $1200{ }^{\circ} \mathrm{C}$ and -10.5 (QFM-2), respectively, with varying amounts of $\mathrm{Cu}$ and $\mathrm{Ni}$ added to the starting composition $(0-10 \mathrm{wt} \%)$. Fig. 19 is a plot of $\mathrm{O}$ solubility in matte as a function of $\mathrm{Ni} / \mathrm{Fe}$ and $\mathrm{Cu} / \mathrm{Fe}$. It is evident that $\mathrm{Ni} / \mathrm{Fe}$ has the largest effect on the solubility of $\mathrm{O}$ in the matte, which decreases by almost $\sim 50 \%$ at a Ni/Fe of 0.17 . The $\mathrm{Cu}$ content of the matte has a more subtle effect, with the $\mathrm{O}$ content decreasing by less than $10 \%$ at a $\mathrm{Cu} / \mathrm{Fe}$ of 0.16 .

Previous studies (Kaiser and Elliott, 1986; Celmer, 1988; Yoshiki-Gravelsins and Toguri, 1993; Brenan and Caciagli, 2000; Rose and Brenan, 2001; Brenan and Rose, 2002; Mungall et al., 2005; Kress, 2007), have shown that increasing the molar fractions of $\mathrm{Ni}$ and $\mathrm{Cu}$ in the matte led to a decrease of the molar fraction of $\mathrm{O}$ in the matte.

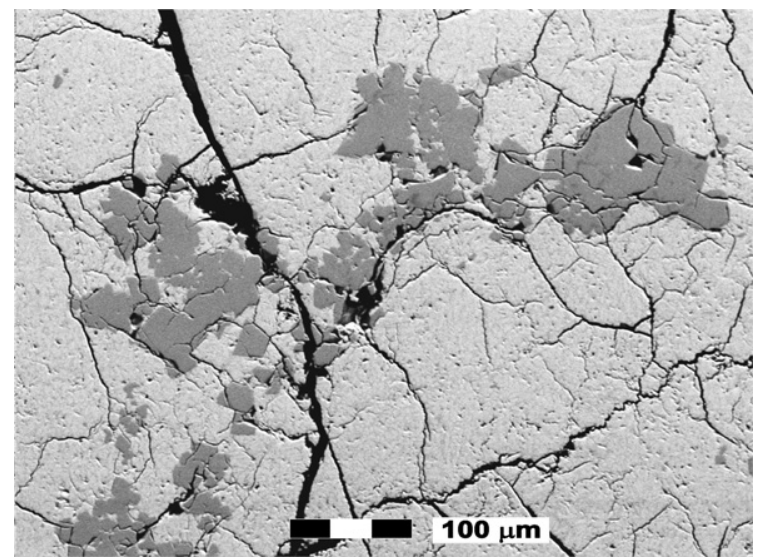

Fig. 10. Subhedral to euhedral chromite crystals that have crystallised directly from the sulphide-rich matte in run $\mathrm{FeOSCr} 1$. Dark grey crystals are chromite and light grey matrix are mss + FeSO.
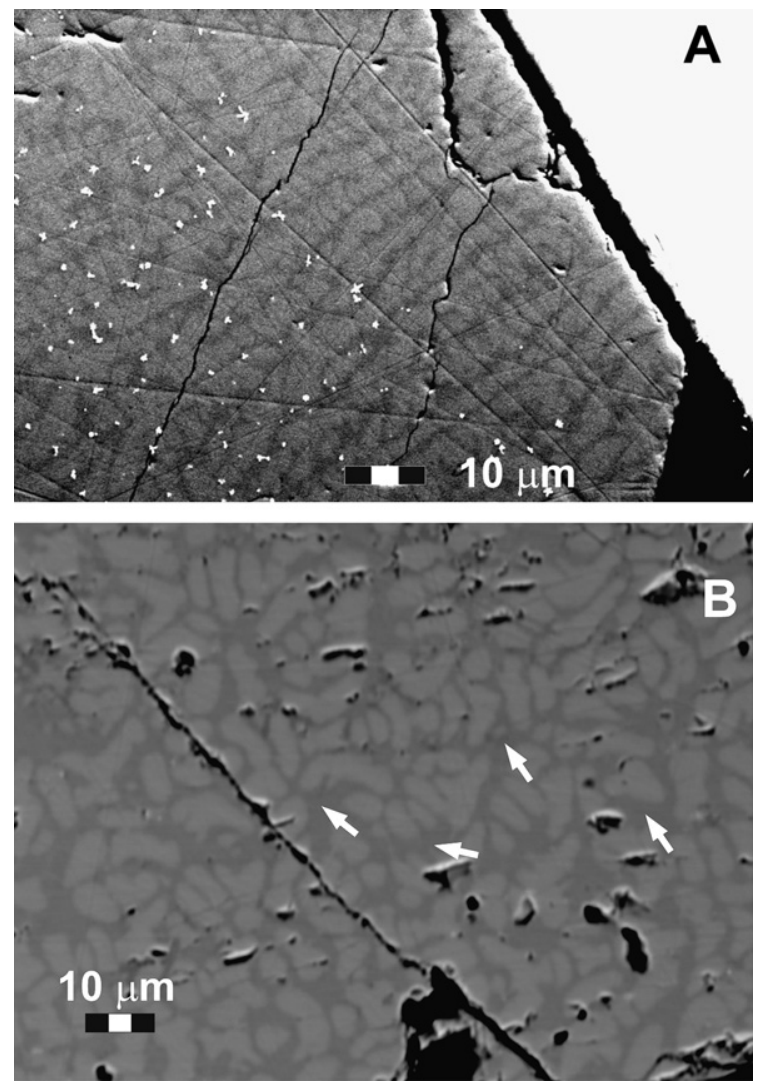

Fig. 11. (A) Backscatter electron image of run FeOS2. Round light coloured grains are mss, whereas the dark phase in the interstitial spaces consists of stoichiometric FeSO. White crystals are PtFe quench nuggets. (B) Textural relationship between FeS and FeSO interstitial phase in run $\mathrm{FeOSCr} 1$. It is clear that the $\mathrm{FeSO}$ phase (marked by white arrows) is in the interstitial spaces between grains of $\mathrm{FeS}$.

The relationship between $\mathrm{O}$ solubility in $\mathrm{Fe}-\mathrm{S}-\mathrm{O}$ mattes and its $\mathrm{Cu}$ content, determined in this study is different to that of $\mathrm{Ni}$, a conclusion that disagrees with the work 

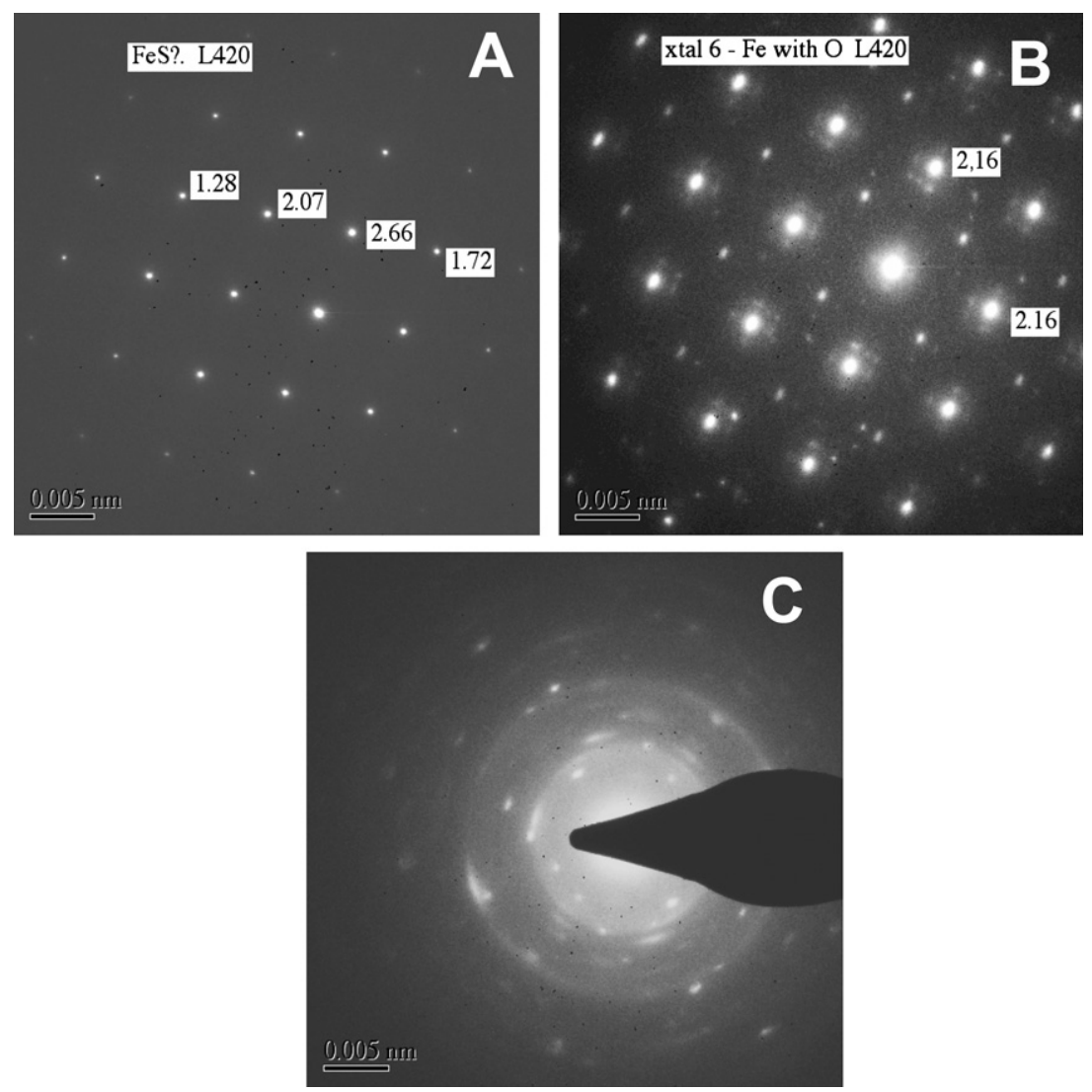

Fig. 12. Selected area diffraction pattern (SADP) of phases found in the sulphide-rich quenched samples. Numbers depicted in (A) and (B) are lattice parameters.

of Yoshiki-Gravelsins and Toguri (1993). However, Yoshiki-Gravelsins and Toguri (1993) compared their experimental results for $\mathrm{Ni}-\mathrm{Fe}-\mathrm{S}-\mathrm{O}$ mattes with previous studies (Kaiser and Elliott, 1986) where the experiments were conducted at different $T, f \mathrm{O}_{2}$ and $f \mathrm{~S}_{2}$, making it impossible to compare the effect of $\mathrm{Cu}$ and $\mathrm{Ni}$ on the solubility of $\mathrm{O}$ in mattes with confidence. Kaiser and Elliott (1986) and Somsiri and Gaskell (1995) studied the solubility of $\mathrm{O}$ in $\mathrm{Cu}-\mathrm{Fe}-\mathrm{S}$ mattes as a function of $f \mathrm{~S}_{2}, \mathrm{fO}_{2}$ and melt composition. They fitted their experimental results to the following equation:

$[\mathrm{O}]_{\text {matte }}=a \times f \mathrm{O}_{2}^{b} \times f \mathrm{~S}_{2}^{c} \times\left(1+9 \times W_{\mathrm{Fe}}\right)^{d}$

where $[\mathrm{O}]_{\text {matte }}$ is the $\mathrm{O}$ content of the matte in $\mathrm{wt} \% ; a, b, c$ and $d$ are empirical fitting constants; and $W_{\mathrm{Fe}}$ is the $\mathrm{Fe} /(\mathrm{Cu}+\mathrm{Fe})$ weight ratio of the matte. At $1200{ }^{\circ} \mathrm{C}$, Kaiser and Elliott (1986) obtained:

$[\mathrm{O}]_{\text {matte }}=2.5 \times f \mathrm{O}_{2}^{0.200} \times f \mathrm{~S}_{2}^{-0.142} \times\left(1+9 \times W_{\mathrm{Fe}}\right)^{2.19}$.

Eq. (6), although useful for $\mathrm{Cu}$-rich compositions cannot be applied to situations were Ni is also present. Moreover, neither Kaiser and Elliott (1986) or Somsiri and Gaskell (1995) included the effect of $T$ on their fits. What is needed is a parameterisation that allows the calculation of $\mathrm{O}$ solubility in the matte as a function of $\mathrm{Ni}$ and $\mathrm{Cu}$ contents of the matte as well as $T, f \mathrm{O}_{2}$ and $f \mathrm{~S}_{2}$. By expanding the data fit for the $\mathrm{Fe}-\mathrm{S}-\mathrm{O}$ system described by Eq. (4) to accommo- date for the effects of $\mathrm{Cu}$ and $\mathrm{Ni}$ to the solubility of $\mathrm{O}$ the following fit is produced:

$$
\begin{aligned}
\ln [\mathrm{O}]_{\text {matte }}= & -2.99+\frac{17550}{T(K)}+0.334 \ln f \mathrm{O}_{2}-0.149 \ln f \mathrm{~S}_{2} \\
& -0.425[\mathrm{Ni}]_{\text {matte }}-0.337[\mathrm{Cu}]_{\text {matte }} \\
& +1.99 \times 10^{-4}[\mathrm{Ni}]_{\text {matte }}^{2}-2.83 \times 10^{-4}[\mathrm{Cu}]_{\text {matte }}^{2} \\
& -0.0064[\mathrm{Ni}]_{\text {matte }} \times[\mathrm{Cu}]_{\text {matte }}
\end{aligned}
$$

where $[\mathrm{Ni}]_{\text {matte }}$ and $[\mathrm{Cu}]_{\text {matte }}$ are the concentrations of $\mathrm{Ni}$ and $\mathrm{Cu}$ in the matte in weight percent, and $\chi_{v}^{2}=3.28$.

Fig. 20 is a comparison between measured and calculated $\mathrm{O}$ contents in $\mathrm{Cu}-\mathrm{Ni}-\mathrm{Fe}-\mathrm{S}-\mathrm{O}$ mattes. As with the $\mathrm{Fe}-\mathrm{S}-\mathrm{O}$ system, the fit between the calculated and measured $\mathrm{O}$ is excellent as shown by the reasonably small value of $\chi_{v}^{2}$ displayed by the fit.

The implication for natural systems is that the presence of $\mathrm{Ni}$, and to a lesser extent $\mathrm{Cu}$, in a matte will decrease its molar proportion of $\mathrm{O}$ relative to $\mathrm{S}$. As a result, the composition of a matte in the $\mathrm{Fe}-\mathrm{Cu}-\mathrm{Ni}-\mathrm{O}-\mathrm{S}$ system may not fall on the O-rich side of the magnetite-mss cotetic at an $\mathrm{fO}_{2}$ defined by the QFM buffer depending on the $\mathrm{Ni}$ and $\mathrm{Cu}$ contents of the matte. $\mathrm{Ni}$ and $\mathrm{Cu}$-rich mattes are likely to crystallise mss first rather than magnetite, in agreement with empirical observations (e.g. Doyle and Naldrett, 1987). 

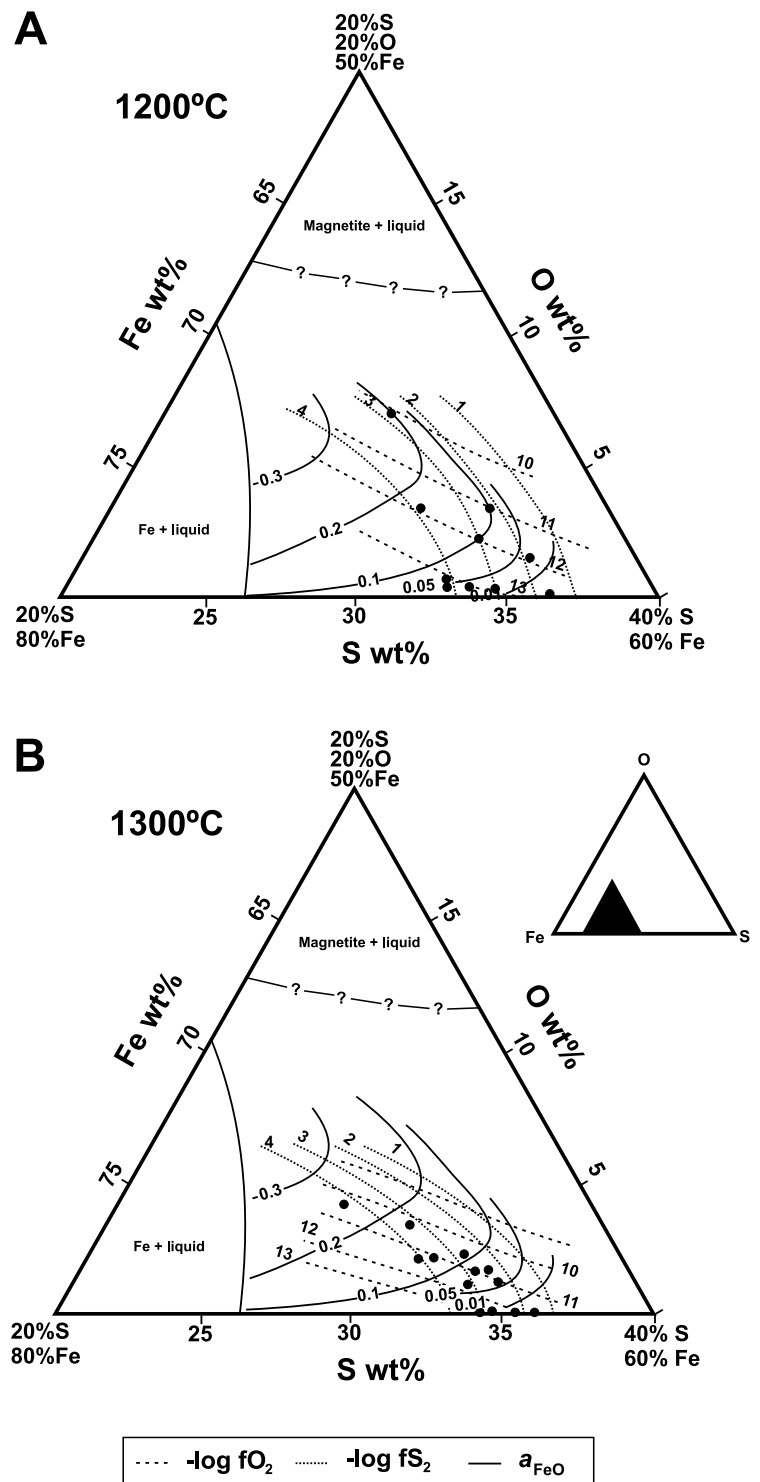

Fig. 13. Empirical contours of $-\log f \mathrm{~S}_{2}$ and $-\log f \mathrm{O}_{2}$, and calculated contours of the $a_{\mathrm{FeO}}$ (Shima and Naldrett, 1975) in a portion of the ternary phase diagram for the system Fe-S-O at $1200^{\circ} \mathrm{C}$ and $1300{ }^{\circ} \mathrm{C}$ following Shima and Naldrett (1975) but contoured in the light of the data presented in this study.

\section{DISCUSSION}

\subsection{Implications of oxygen solubility in mattes}

Most natural occurrences of magnetite associated with magmatic sulphides are the result of desulphurisation, either by high-grade metamorphic fluids (e.g. Curaçá Valley, Brazil; Maier and Barnes, 1996), and late-magmatic hydrothermal fluids (JM reef, Stillwater, USA; Li and Ripley, 2006), or in most cases, the result of direct precipitation from a silicate melt. In addition to the aforementioned modes of magnetite formation, there are cases where magnetite is associated with sulphide and appears to have crystallised directly from an immiscible sulphide-rich matte.
Our results indicate that a natural sulphide-rich matte should increase its $\mathrm{O}$ abundance as mss crystalises. What happens to the dissolved oxygen is not very well known. Naldrett (1969) suggested that sulphide-rich mattes are closed systems with respect to their $\mathrm{O}$ content. Indeed, massive sulphides, such as the Ovoid body in the Voisey's Bay $\mathrm{Ni}-\mathrm{Cu}-\mathrm{Co}$ deposit, display abundant disseminated magnetite, which is uniformly distributed within the ore (Naldrett et al., 2000) and not concentrated in the matte/silicate-melt boundaries, like in deposits such as Kambalda (Western Australia-Frost and Groves, 1989) or Sudbury (Ontario, Canada-Magyarosi et al., 2002). The Ovoid body in Voisey's Bay, may then be considered a closed system with regards to its $\mathrm{O}$ content. Other ore deposits, do not display such a clear picture with regards to the fate of the matte's $\mathrm{O}$ abundances. For example, the Kambalda massive Ni-sulphide deposit features, in addition to rare disseminated magnetite (Heath et al., 2001), has Cr-rich magnetite within the massive sulphide ore, in close proximity to komatiitic melt inclusions (Frost and Groves, 1989). Moreover, in some sections of the Sudbury igneous complex (e.g. Copper Cliff South Mine) up to $5 \mathrm{wt} \%$ primary magnetite associated with the massive sulphide ore are present (e.g. Magyarosi et al., 2002). Moreover, (Magyarosi et al., 2002) describes that magnetite is more common along the disseminated/massive ore interface and not uniformly disseminated in the massive ore like in the Voisey's Bay massive sulphide. The distribution of magnetite in the massive sulphides in both Kambalda and Sudbury seems to be in contrast with that observed in the Voisey's Bay massive sulphide. Further understanding on how the magnetites and $\mathrm{Cr}$ rich spinels formed in Sudbury and Kambalda respectively is then necessary to understand the fate of oxygen dissolved in sulphide-rich mattes.

\subsubsection{Sudbury (Ontario, Canada)}

The Sudbury Igneous Complex (SIC) is thought to have formed through a meteoritic impact (e.g. Grieve, 1994), which led to the formation of a silicate melt that was well above its liquidus temperature $\left(1700{ }^{\circ} \mathrm{C}\right.$ according to Keays and Lightfoot, 2004). The initial high temperature of the SIC melt made it able to dissolve as much as $5000 \mathrm{ppm} \mathrm{S}$ (Keays and Lightfoot, 2004). As it cooled down to its liquidus temperature (ca. $1180{ }^{\circ} \mathrm{C}$ ), the silicate melt became sulphide saturated, producing the mass sulphide ores present today (Keays and Lightfoot, 2004). Keays and Lightfoot (2004) estimated that the $f \mathrm{O}_{2}$ when the silicate melt reached its liquidus temperature was $\sim$ QFM-1. They calculated a $\mathrm{Ni}$ and $\mathrm{Cu}$ tenor of the sulphide liquid in equilibrium with the silicate melt and they obtained $4.2 \mathrm{wt} \% \mathrm{Ni}$ and $4.5 \mathrm{wt} \%$ $\mathrm{Cu}$. At $1180{ }^{\circ} \mathrm{C}, \mathrm{QFM}-1$ and an $f \mathrm{~S}_{2}$ of 0.12 bars (estimated based on the relationship between $a_{\mathrm{FeO}}$ in the silicate melt, $f \mathrm{O}_{2}$ and sulphur content following O'Neill and Mavrogenes, 2002), the calculated solubility of $\mathrm{O}$ in a matte under these conditions using Eq. (4), gives a maximum $\mathrm{O}$ content of $5.31 \mathrm{wt} \%$ ( $\sim 20 \mathrm{wt} \%$ magnetite in the matte). However, the observed magnetite content of the SIC's sulphide is between 2 and $5 \mathrm{wt} \%$ of primary magnetite, far below the calculated $20 \mathrm{wt} \%$, which indicates that the matte may have 
Table 2

List of sources of data used for the empirical fit described by Eq. (4)

\begin{tabular}{|c|c|c|c|c|c|c|}
\hline Data source & $n$ & Rejections $^{\mathrm{a}}$ & Range of $-\log f \mathrm{~S}_{2}$ & Range of $-\log f \mathrm{O}_{2}$ & Range of $T\left({ }^{\circ} \mathrm{C}\right)$ & Analytical method \\
\hline This study & 51 & 2 & $1.3-4.96$ & $9.6-15.0$ & $1200-1400$ & EMP and SEM \\
\hline Nagamori and Kameda (1965) & 59 & $\mathrm{All}^{\mathrm{b}}$ & $1.05-2.6$ & $9.4-12.0$ & 1300 & $\mathrm{H}$ extraction \\
\hline Kaiser and Elliott (1986) & 71 & None & $1.62-2.98$ & $8.33-9.56$ & 1195 & $\mathrm{H}$ extraction \\
\hline Somsiri and Gaskell (1995) & 36 & None & $1.6-2.3$ & $8.5-13.72$ & 1300 & IR analysers \\
\hline Blatov et al. (1997) & 25 & $\mathrm{All}^{\mathrm{c}}$ & $1.06-2.26$ & $7.53-11.45$ & 1300 & Unknown \\
\hline Kress (1997) & 15 & 2 & $1.24-3.05$ & $8.5-13.72$ & $1097-1348$ & EMP \\
\hline Brenan and Caciagli (2000) & 6 & 3 & $2.06-4.0$ & $8.1-10.1$ & 1300 & EMP \\
\hline Nagamori and Yazawa (2001) & 12 & None & $2.65-3.48$ & $9.6-12.0$ & 1200 & EMP \\
\hline Rose and Brenan (2001) & 29 & 7 & $1.6-4$ & $8-11.1$ & 1300 & EMP \\
\hline Andrews and Brenan (2002) & 6 & None & $1.7-3$ & $8.1-8.6$ & $1300-1400$ & EMP \\
\hline Brenan and Rose (2002) & 11 & 4 & $1.6-1.9$ & $8.1-9.5$ & 1300 & EMP \\
\hline Mungall et al. (2005) & 4 & None & $1.25-2.2$ & $11.2-12.8$ & $950-1050$ & EMP \\
\hline Kress (2007) & 32 & 11 & $1.09-4.02$ & $7.69-13.57$ & $1248-1449$ & EMP \\
\hline
\end{tabular}

${ }^{\text {a }}$ By default, outliers which represent more than two standard deviations from the mean are rejected.

${ }^{\mathrm{b}}$ Data plots slightly higher than the general trend shown by the data. Possible analytical bias.

${ }^{\mathrm{c}}$ Data of poor quality. No analytical methods described in the manuscript.

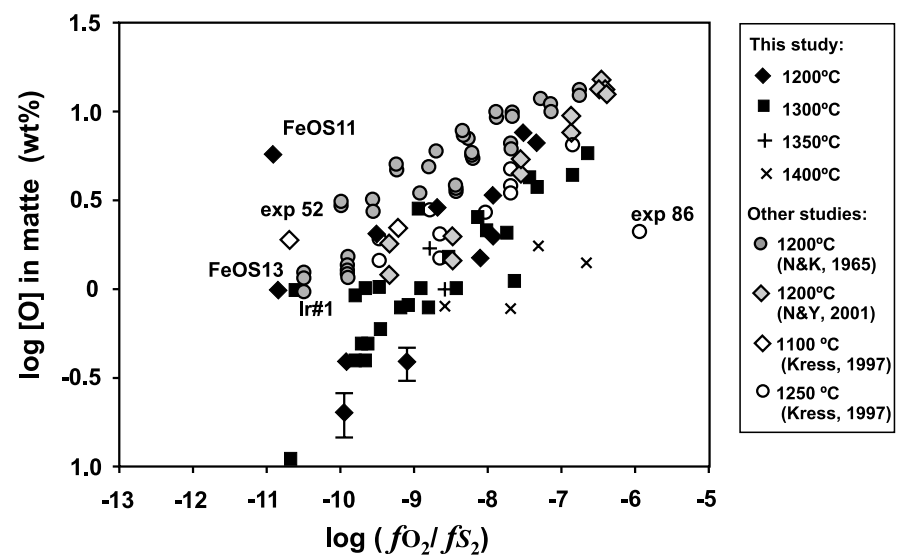

Fig. 14. $\mathrm{O}$ solubility in matte as a function of $\log \left(f \mathrm{O}_{2} / f \mathrm{~S}_{2}\right)$. Note that despite differences in temperature; overall almost of the datasets represented in the figure agree very well with each other. With the exception of a few outliers (run numbers are identified in the figure, exp52 and exp86 are taken from Nagamori and Yazawa, 2001; Kress, 1997, respectively), only the dataset of Nagamori and Kameda (1965) plots at consistently higher $\mathrm{O}$ concentration than other datasets, probably due to an analytical bias.

lost as much as $75 \%$ of its $\mathrm{O}$ content through diffusion to the overlying SIC melt. The diffusion of $\mathrm{O}$ from the massive sulphide into the overlying SIC cumulate pile is consistent with the larger concentration of magnetite in the disseminated ore (Magyarosi et al., 2002), and with the low diffusion rate of $\mathrm{O}$ in silicate melts compared with mattes $\left(\sim 10^{-7} \mathrm{~cm}^{2} / \mathrm{s}\right.$ - Liang et al., 1996-compared to $\sim 2 \mathrm{~cm}^{2} / \mathrm{s}$ in sulphide-Jorgensen and Moyle, 1986), allowing the nucleation of magnetite at the massive ore-disseminated ore interface (Fig. 21A). As the matte cools, mss starts crystallising and the remaining $\mathrm{O}$ in the matte increases leading to the crystallisation of sparse magnetite in the massive ore (Fig. 21B). Note that Szentpéteri et al. (2002) also document the presence of Ti-magnetite, in addition to magnetite associated with the Sudbury massive sulphides (Copper Cliff North Area). The Ti-magnetite is likely the result of direct precipitation from the silicate melt, and therefore it cannot have precipitated from the sulphide-rich matte.

\subsubsection{Kambalda (Western Australia)}

Frost and Groves (1989), in their study of magmatic contacts between immiscible sulphide and komatiite melts in the Kambalda sulphide ores (Western Australia), identified Cr-rich magnetite in close textural association with the Ni-rich sulphide ore. The spinel is localised in the sulphide matrix adjacent to komatiite inclusions in the massive ore and it is concentrated near, but not on, sulphide-komatiite contacts. Subsequent observations by Heath et al. (2001) showed that, in addition to the Cr-rich spinel described by Frost and Groves (1989), primary magnetite is found in the matrix ore $(1-9 \mathrm{wt} \%)$ and to a lesser extent in the massive ore (less than $1 \mathrm{wt} \%$ ). Magnetite enrichment is more pronounced along the boundary between massiveand disseminated-ore types (Woolrich et al., 1981; Heath et al., 2001), which is explained by Naldrett (1969) as the result of $f \mathrm{O}_{2}$ enhancement due to differences in the diffusion coefficients of $\mathrm{O}$ in mattes and silicate melt. These observa- 

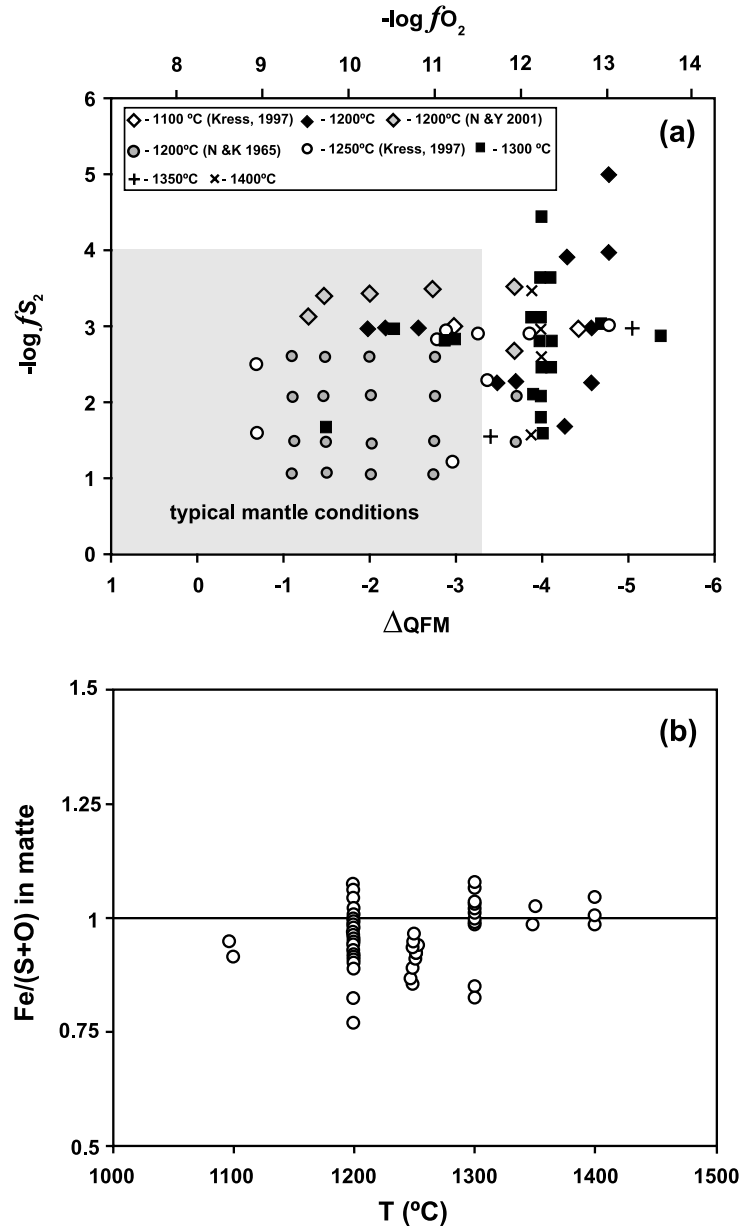

Fig. 15. (a) Oxygen and sulphur fugacity distribution of the different datasets used in this study. (b) $\mathrm{Fe} /(\mathrm{S}+\mathrm{O})$ molar ratio versus temperature. The range of $\mathrm{Fe} /(\mathrm{S}+\mathrm{O})$ molar ratios shown here represents sulphide-rich mattes characteristic to the upper mantle.

tions seem to indicate that a sulphide-rich matte can be considered an open system with regard to its oxygen content, a view which differs from that of Naldrett (1969) who suggested that massive sulphide-rich mattes would form a closed system.

The magnetite present in the ore as well as the Cr-rich spinel, are thought to be primary in origin (Frost and Groves, 1989; Heath et al., 2001). It is necessary to characterise the mechanisms that allowed the crystallisation of these two different types of primary magnetites in order to understand how $\mathrm{O}$ behaves during the fractional crystallisation of sulphide-rich mattes. Ewers et al. (1976) suggested that the presence of $\mathrm{Cr}$-rich spinels in massive sulphide ores, such as Kambalda, crystallised directly from the sulphide-rich matte. However, direct crystallisation of chromite from a matte is inconsistent with the fact that Cr-rich spinels in Kambalda are not found in sulphide ore, which would be the case if they crystallised directly, but they are concentrated near ore-komatiite interfaces. We re-evaluated the interpretation of Ewers et al. (1976) in view of the structural matte constituents that were iden-

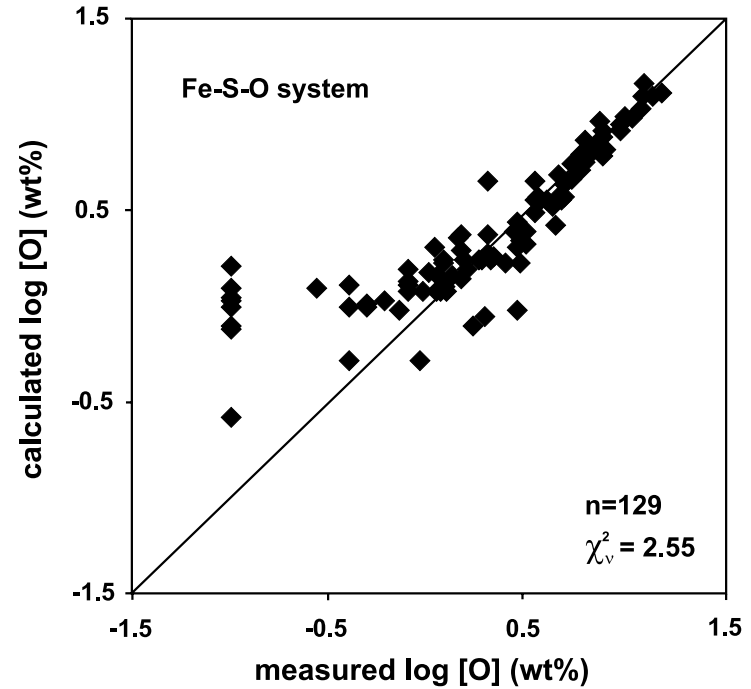

Fig. 16. Comparison between measured $\mathrm{O}$ in matte and $\mathrm{O}$ solubility in the matte calculated through Eq. (4). The results of the fit are excellent as shown by its high $\chi_{v}^{2}$ value.

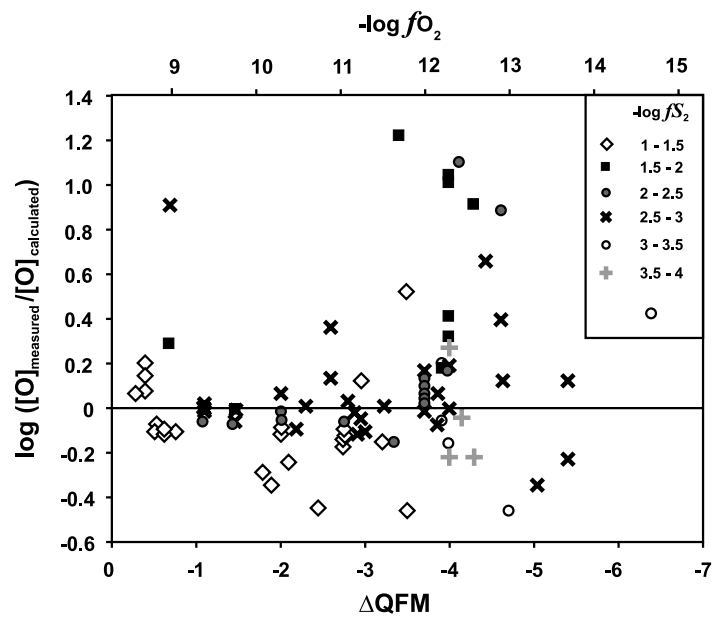

Fig. 17. Plot of the difference between measured $\mathrm{O}$ and $\mathrm{O}$ calculated through Eq. (7), versus $f \mathrm{O}_{2}$ at different intervals of $f \mathrm{~S}_{2}$. The outliers identified this way show no dependence on either $f \mathrm{O}_{2}$ or $f \mathbf{S}_{2}$.

tified previously and in the light of run FeOSCr1, which was carried out to determine the solubility of $\mathrm{Cr}$ in a matte.

Our results, as well as $\mathrm{Cr}$ solubility data from sulphides featured in Brenan and Rose (2002), show that in a Cr-saturated matte, chromite will crystallise before mss. However, in Kambalda, the sulphide-associated $\mathrm{Cr}$-rich spinel is found in intergrowths with sulphides, indicating that the Cr-rich spinel crystallised at the same time or shortly after the onset of sulphide crystallisation. Because sulphide crystallised before the Cr-rich spinel, the residual matte will become increasingly rich in the FeSO component and therefore O. The scarcity of any kind of spinel in the crystallised sulphide (Frost and Groves, 1989; Heath et al., 2001) shows that the matte lost most of its $\mathrm{O}$ to the overlying silicate melt. The excess $\mathrm{O}$ reacted with the $\mathrm{Cr}$ from the 

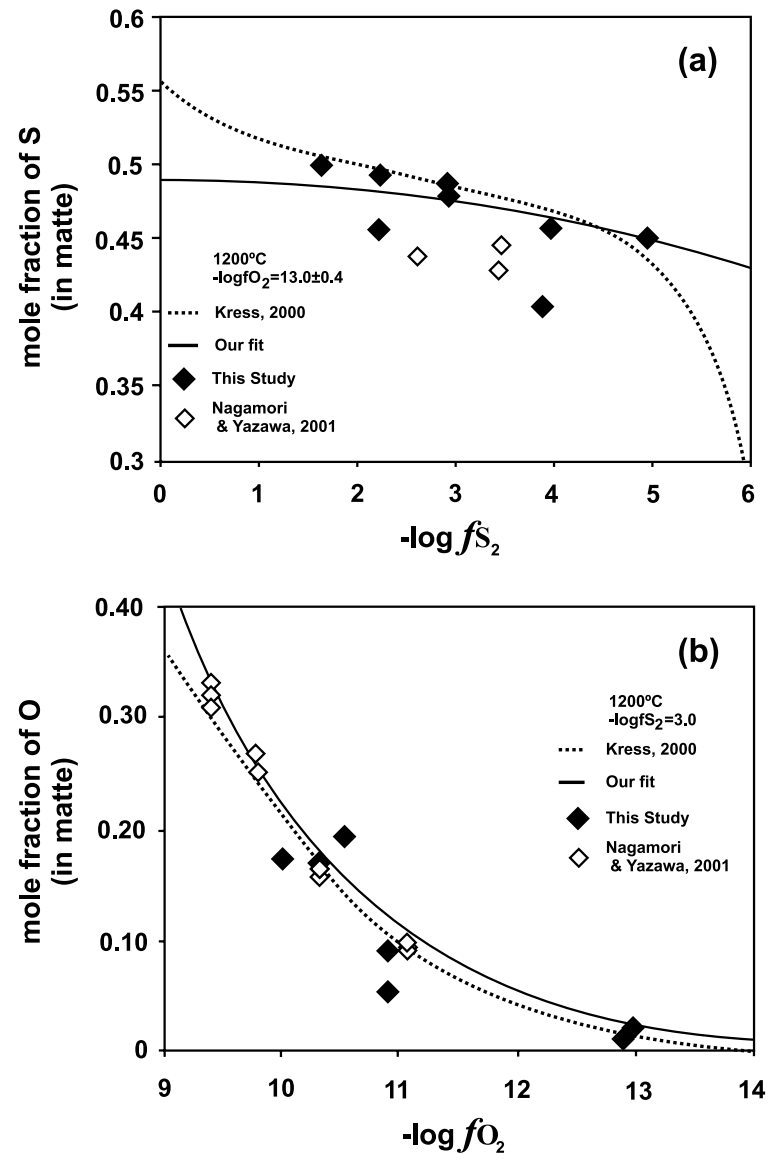

Fig. 18. Comparison between melt composition data as a function of $f \mathrm{O}_{2}$ (a) and $f \mathrm{~S}_{2}$ (b) and the associated asymmetric regular solution thermochemical formulation for the system $\mathrm{Fe}-\mathrm{S}-\mathrm{O}$ of Kress (2000). The full line represents the expected $\mathrm{O}$ and $\mathrm{S}$ concentrations of the matte as calculated through Eq. (4).

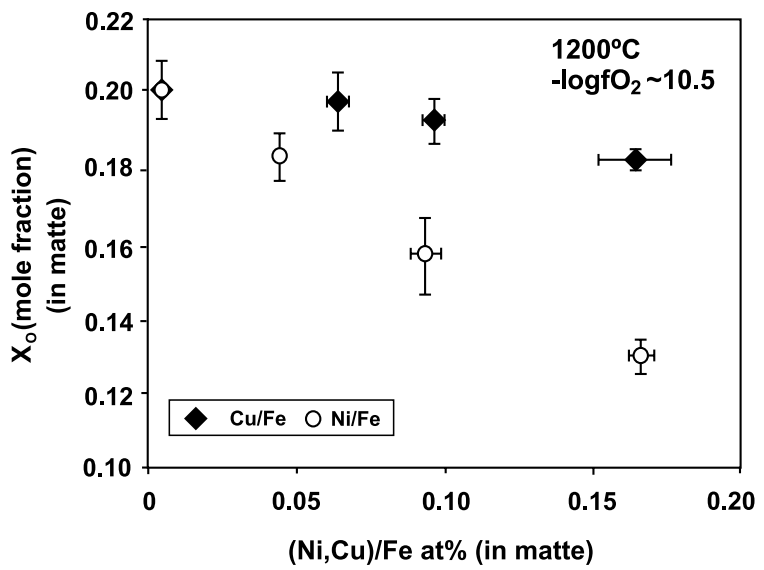

Fig. 19. Oxygen concentrations in matte as a function of $\mathrm{Cu} / \mathrm{Fe}$ and $\mathrm{Ni} / \mathrm{Fe}$ atomic ratios.

komatiite melt inclusions leading to the crystallisation of spinel near, but not at, the boundaries between komatiite melt inclusions and matte (Fig. 22). The precipitation of $\mathrm{Cr}$-rich spinel is enhanced by the relative low solubility of

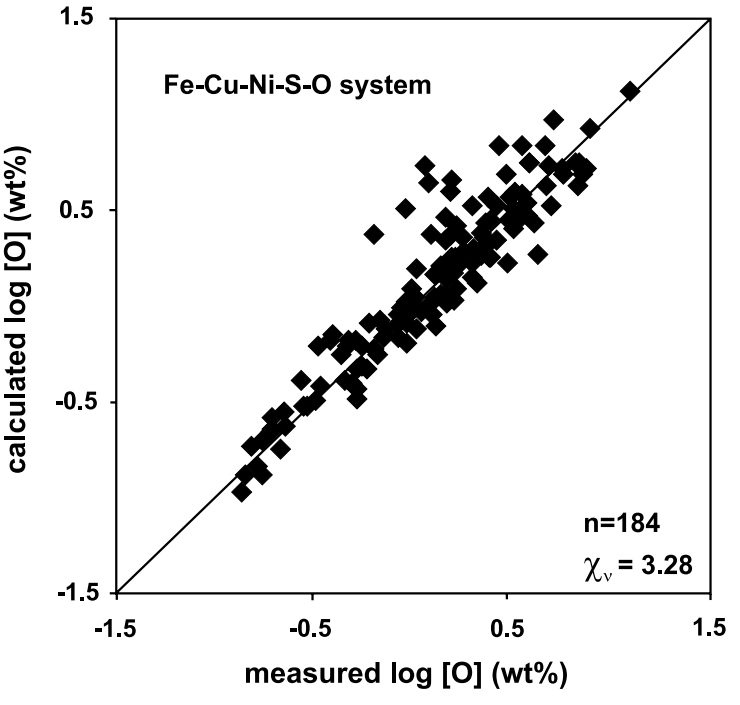

Fig. 20. Calculated $\mathrm{O}$ contents in the matte versus measured $\mathrm{O}$. The agreement between measured $\mathrm{O}$ and calculated $\mathrm{O}$ is excellent.

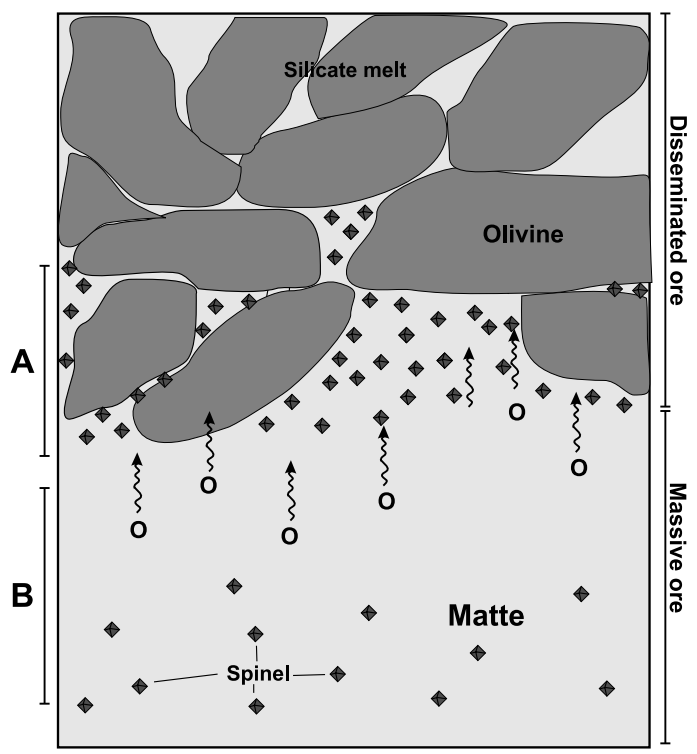

Fig. 21. Possible occurrence of spinel associated with magmatic sulphides. (A) Spinel at the massive ore-disseminated ore interface. (B) Spinel disseminated through the massive sulphide ore. C bands of cumulate spinel that have settled in the massive sulphide ore.

$\mathrm{Cr}$ in sulphide-rich matte as shown in run FeOSCr1 and by Brenan and Rose (2002). This hypothesis is in agreement with the observations of Frost and Groves (1989) who argue that "only limited $\mathrm{O}$ will have dissolved in the komatiite melt enclosed in massive sulphides, the excess being concentrated along the sulphide-silicate contacts". A similar mechanism was proposed by Dowling et al. (2004) (see Fig. 22) to explain the presence of chromites on the komatiite-ore interface of the Silver Swan ore body (Black Swan area,Western Australia). Kambalda's massive sulphides are $\mathrm{Ni}$-rich, with $\mathrm{Ni} / \mathrm{Fe} \sim 0.30$, and relatively $\mathrm{Cu}$-poor with only $\sim 1 \mathrm{wt} \% \quad \mathrm{Cu}$ (Cowden et al., 1986). Murck and 

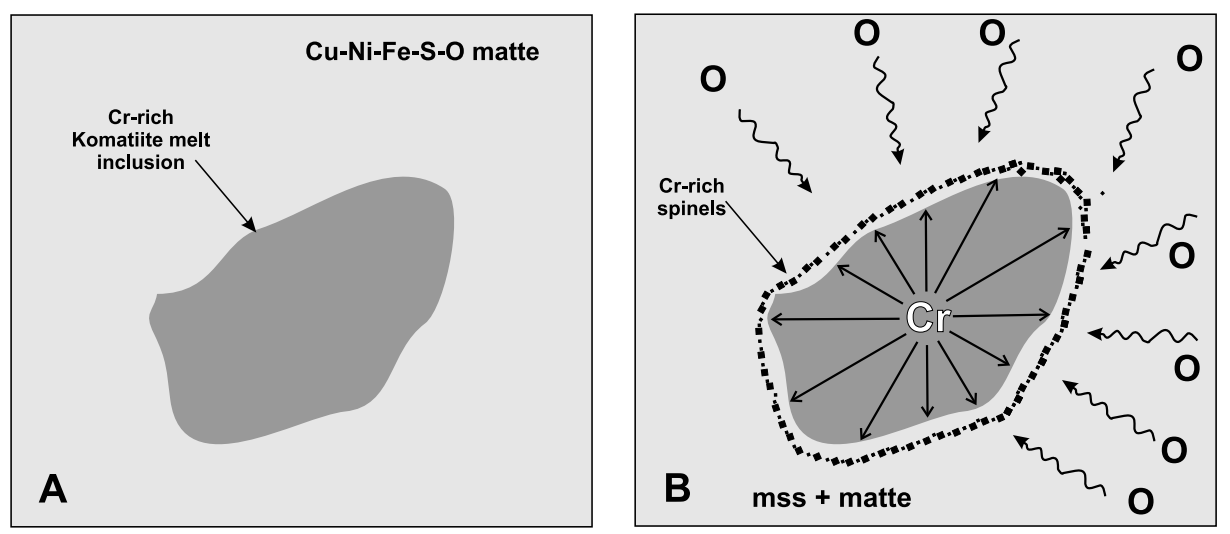

Fig. 22. (A) Komatiite melt inclusions in sulphide-rich matte with $\mathrm{O}$ dissolved. (B) As the matte crystallises mss, the molar fraction of $\mathrm{O}$ increases and reacts with the $\mathrm{Cr}$ diffusing out of the komatiite melt inclusions, forming spinel near the boundaries between the matte and the inclusions.

Campbell (1986), studied the behaviour of chromium in basic and ultrabasic melts, and showed that the $f \mathrm{O}_{2}$ of a melt can be estimated from the composition of the coexisting spinel from the following relationship:

$f \mathrm{O}_{2} \alpha X_{\mathrm{Fe}^{3+}} /\left(X_{\mathrm{Cr}^{3+}}+X_{\mathrm{Al}^{3+}}+X_{\mathrm{Fe}^{3+}}\right)$

where $X$ represents the mole fraction of the element in question. Using the compositional data for the spinels associated with Kambalda sulphides of Frost and Groves (1989), $X_{\mathrm{Fe}^{3+}} /\left(X_{\mathrm{Fe}^{3+}}+X_{\mathrm{Al}^{3+}}+X_{\mathrm{Cr}^{3+}}\right)=0.14$. The $f \mathrm{O}_{2}$ value that corresponds to a given ratio depends also on temperature. In Fig. 5 of Murck and Campbell (1986) a $X_{\mathrm{Fe}^{3+}} /\left(X_{\mathrm{Fe}^{3+}}+X_{\mathrm{Al}^{3+}}+X_{\mathrm{C}^{3+}}\right)$ of 0.14 corresponds to an $f \mathrm{O}_{2}$ close to the QFM buffer at $1400{ }^{\circ} \mathrm{C}$. From Eq. (7), a matte with a $\mathrm{Ni} / \mathrm{Fe}$ of $0.3(\sim 20 \mathrm{wt} \% \mathrm{Ni})$ at $\mathrm{QFM}$, a $f \mathrm{~S}_{2}$ of 0.1 bars and $1400{ }^{\circ} \mathrm{C}$ should have $7.3 \mathrm{wt} \% \mathrm{O}$ in the matte. Under these circumstances, sulphide will crystallise before $\mathrm{Cr}$-rich spinel, since the composition of the matte will fall on the O-poor side of the sulphide-spinel cotetic. However, $X_{\mathrm{O}}$ in the matte will increase until such point where the sulphide/spinel cotetic is reached and co-crystallisation of spinel, chalcopyrite and pentlandite will occur, which is consistent with the textural intergrowths characteristic of the sulphide-associated spinels in the Kambalda ores (Frost and Groves, 1989). Unlike Sudbury, the Kambalda matte lost the bulk of its $\mathrm{O}$ content to the overlying silicate melt, which is consistent with the observations of Heath et al. (2001) that the massive ore has negligible amounts of magnetite. The crystallisation of Cr-rich spinel near the ore-komatiite melt interface is taken to be evidence of that $\mathrm{O}$ loss.

\section{CONCLUDING REMARKS}

The solubility of $\mathrm{O}$ in sulphide-rich mattes can be quantified and parameterised as a function of $f \mathrm{O}_{2}, f \mathrm{~S}_{2}$, temperature and melt composition, by a series of empirical fits to experimental data from this study and the literature. The empirical expressions described here, are of potential use to estimate the initial $\mathrm{O}$ content of natural $\mathrm{Cu}$ - and Ni-bearing sulphide-rich mattes under supra-liquidus conditions.
We found that in the case of Kambalda and Sudbury, the sulphide-rich matte likely lost much of its dissolved $\mathrm{O}$ through diffusion towards the overlying silicate melt. The diffusion of $\mathrm{O}$, out of the sulphide-rich matte and into the silicate melt, may have led to the precipitation of magnetite and/or chromite near or on the boundaries between the matte and the silicate melt. We conclude that most massive sulphide-rich mattes represent open systems in relation to their $\mathrm{O}$ content. We have also found evidence for the presence of the FeSO stoichiometry, previously predicted by Kress (2000), as a main O-bearing species and a true structural constituent of a sulphide-rich matte.

\section{ACKNOWLEDGMENTS}

We thank Michael Shelley, William Hibberson, David Clark, Dean Scott, for their help throughout the experimental work. Ashley Norris for his assistance while using the CAMECA SX100 electron microprobe; Frank Brink for his help while using the JEOL 6400 SEM. This article benefited greatly from insightful comments and constructive criticism from Guilherme Mallmann, Reid Keays, Stephen J. Barnes, Jim Mungall and Tony Naldrett, and reviews by Edward Ripley, Pedro Jugo, Chusi Li and an anonymous reviewer.

\section{APPENDIX A. SUPPLEMENTARY DATA}

Supplementary data associated with this article can be found, in the online version, at doi:10.1016/j.gca.2008. 03.009.

\section{REFERENCES}

Andrews D. R. A. and Brenan J. M. (2002) The solubility of ruthenium in sulfide liquid: implications for platinum group mineral stability and sulfide-melt/silicate-melt partitioning. Chem. Geol. 192, 163-181.

Ballhaus C. (1993) Redox states of lithospheric and asthenospheric upper mantle. Contrib. Mineral. Petr. 114, 331-348.

Blatov I. A., Burylev B. P., Tsemekhman L. S. H. and Litvinov S. L. (1997) Thermodynamics of the reaction of components of the $\mathrm{Fe}-\mathrm{S}-\mathrm{O}$ system in equilibrium with a $\mathrm{CO}-\mathrm{CO}_{2}-\mathrm{SO}_{2}$ gas phase at $1300^{\circ} \mathrm{C}$. Russian Metall.: Metally 6, 37-40. 
Bog S. and Rosenqvist T. (1958) Thermodynamics of metal sulfides. Nor Tek-Naturvitensk 12, 1-20.

Brenan J. and Rose L. A. (2002) Experimental constraints on the wetting of chromite by sulfide liquid. Can. Mineral. 40, 11131126.

Brenan J. M. and Caciagli N. C. (2000) Fe-Ni exchange between olivine and sulphide liquid: implications for oxygen barometry in sulphide-saturated magmas-contrasting compositions and phase relations in eruption pumice and Kilauea Iki lava lake. Geochim. Cosmochim. Acta 64(2), 307-320.

Campbell I. H., Naldrett A. J. and Barnes S. J. (1983) A model for the origin of the platinum rich sulfide horizons in the Bushveld and Stillwater complexes. J. Petrol. 24(2), 133-165.

Celmer R. (1988) The Distribution of Minor Elements in Nickel Matte Smelting. National Library of Canada.

Chase M. W. (1998) NIST-JANAF Thermodynamic Tables. National Institute of Standards and Technology, Washington, DC, USA.

Christie D. M., Carmichael I. S. E. and Langmuir C. H. (1986) Oxidation states of mid-ocean ridge basalt glasses. Earth Planet. Sci. Lett. 79, 379-411.

Cowden A., Donaldson M. J., Naldrett A. J. and Campbell I. H. (1986) Platinum-group elements and gold in the komatiitehosted $\mathrm{Fe}-\mathrm{Ni}-\mathrm{Cu}$ sulfide deposits at Kambalda, Western Australia. Econ. Geol. 81, 1226-1235.

Darken L. S. and Gurry R. W. (1946) The system iron-oxygen. I: The wüstite field and related equilibria. J. Am. Chem. Soc. 67, 1398-1412.

Dowling S. E., Barnes S. J., Hill R. E. T. and Hicks J. D. (2004) Komatiites and nickel sulfide ores of the Black Swan area, Yilgarn Craton, Western Australia. 2: Geology and genesis of the orebodies. Miner. Deposita 39(7), 707-728.

Doyle C. D. and Naldrett A. J. (1987) Oxygen content of "sulfide" magma and its effect on the partitioning of nickel between coexisting olivine and molten ores. Econ. Geol. 82, 208-211.

Ewers W. E., Graham J., Hudson D. R. and Rolls J. M. (1976) Crystallization of chromite from nickel-iron sulphide melts. Contrib. Mineral. Petr. 54(1), 61-64.

Fleet M. E., Liu M. and Crocket J. H. (1999) Partitioning of trace amounts of highly siderophile elements in the $\mathrm{Fe}-\mathrm{Ni}-\mathrm{S}$. Geochim. Cosmochim. Acta 63(17), 2611-2622.

Frost K. M. and Groves D. I. (1989) Magmatic contacts between immiscible sulfide and komatiite melts: implications for the genesis of Kambalda sulfide ores. Econ. Geol. 84, 1697-1704.

Gaetani G. A. and Grove T. L. (1999) Wetting of mantle olivine by sulfide melt: implications for Re/Os ratios in mantle peridotite and late-stage core formation. Earth Planet. Sci. Lett. 169, 147163.

Grieve R. A. F. (1994) An impact model of the Sudbury structure. In Proceedings of the Sudbury-Noril'sk Symposium, pp. 119132. Ontario Geological Survey Special 5, Ottawa.

Heath C., Lahaye Y., Stone W. and Lambert D. (2001) Origin of variations in nickel tenor along the strike of the Edwards Lode nickel sulfide orebody, Kambalda, Western Australia. Can. Mineral. 39, 655-671.

Jana D. and Walker D. (1997) The influence of sulfur on partitioning of siderophile elements. Geochim. Cosmochim. Acta 61(24), 5255-5277.

Jorgensen F. R. A. and Moyle F. J. (1986) Gas diffusion during the thermal analysis of pyrite. J. Therm. Anal. Calorim. 31(1), 145156.

Kaiser D. L. and Elliott J. F. (1986) Solubility of oxygen and sulfur in copper-iron mattes. Metall. Trans. B 17B, 147-157.

Keays R. R. and Lightfoot P. C. (2004) Formation of Ni-Cuplatinum group element sulfide mineralization in the Sudbury impact melt sheet. Mineral. Petr. 82(3), 217-258.
Kress V. (1997) Thermochemistry of sulfide liquids. I: The system O-S-Fe at 1 bar. Contrib. Mineral. Petr. 127, 176-186.

Kress V. (2000) Thermochemistry of sulfide liquids. II: Associated solution model for sulfide liquids in the system $\mathrm{O}-\mathrm{S}-\mathrm{Fe}$. Contrib. Mineral. Petr. 139, 316-325.

Kress V. (2007) Thermochemistry of sulfide liquids. III: Ni-bearing liquids at 1 bar. Contrib. Mineral. Petr. 154, 191-204.

Larocque A. C. L., Stimac J. A., Keith J. D. and Huminicki M. A. E. (2000) Evidence for open-system behavior in immiscible Fe$\mathrm{S}-\mathrm{O}$ liquids in silicate magmas: implications for contributions of metals and sulfur to ore-forming fluids. Can. Mineral. 38, $1233-1249$.

Lazar C., Walker D. and Walker R. J. (2004) Experimental partitioning of $\mathrm{Tc}, \mathrm{Mo}, \mathrm{Ru}$, and Re between solid and liquid during crystallization in $\mathrm{Fe}-\mathrm{Ni}-\mathrm{S}$. Geochim. Cosmochim. Acta 68(3), 643-651.

Li C. and Ripley E. M. (2006) Formation of Pt-Fe alloy by desulfurization of Pt-Pd sulfide in the J-M reef of the Stillwater complex, Montana. Can. Mineral. 44, 895-903.

Liang L. C. (1991) Study of oxygen peak shifts among some minerals using a tungsten-silicon multilayer pseudo-crystal. $X$ Ray Spectrom. 20, 89-90.

Liang Y., Richter F. M., Davis A. M. and Watson E. B. (1996) Diffusion in silicate melts. I: Self diffusion in $\mathrm{CaO}-\mathrm{Al}_{2} \mathrm{O}_{3}-\mathrm{SiO}_{2}$ at $1500{ }^{\circ} \mathrm{C}$ and $1 \mathrm{GPa}$. Geochim. Cosmochim. Acta $\mathbf{6 0}(22)$, 4353-4367.

Magyarosi Z., Watkinson D. H. and Jones P. C. (2002) Mineralogy of $\mathrm{Ni}-\mathrm{Cu}$-platinum-group element sulfide ore in the 800 and 810 orebodies, Copper Cliff South Mine, and $\mathrm{P}-\mathrm{T}-\mathrm{X}$ conditions during the formation of platinum-group minerals. Econ. Geol. 97, 1471-1486.

Maier W. D. and Barnes S. J. (1996) Unusually high concentrations of magnetite at Caraíba and other $\mathrm{Cu}$-sulfide deposites in the Curaçá valley, Bahia, Brazil. Can. Mineral. 34, 717-731.

McGuire A. V., Francis C. A. and Dyar M. D. (1992) Mineral standards for electron microprobe analysis of oxygen. $\mathrm{Am}$. Mineral. 77, 1087-1091.

Mungall J. E. (2007) Crystallization of magmatic sulfides: an empirical model and application to Sudbury ores. Geochim. Cosmochim. Acta 71(11), 2809-2819.

Mungall J. E., Andrews D. R. A., Cabri L. J., Sylvester P. J. and Ubrett M. (2005) Partitioning of $\mathrm{Cu}, \mathrm{Ni}, \mathrm{Au}$ and platinumgroup elements between monosulfide solid solution and sulfide malt under controlled oxygen and sulfur fugacities. Geochim. Cosmochim. Acta 69(17), 4349-4360.

Murck B. W. and Campbell I. H. (1986) The effects of temperature, oxygen fugacity and melt composition on the behavior of chromium in basic and ultrabasic melts. Geochim. Cosmochim. Acta 50, 1871-1887.

Nagamori M., Hatakeyama T. and Kameda M. (1970) Thermodynamics of $\mathrm{Fe}-\mathrm{S}$ melts between 1100 and $1300^{\circ} \mathrm{C}$. Trans. Jpn. Inst. Met. 11, 190-194.

Nagamori M. and Kameda M. (1965) Equilibria between Fe-S-O system melts and $\mathrm{CO}-\mathrm{CO}_{2}-\mathrm{SO}_{2}$ gas mixtures at $1200{ }^{\circ} \mathrm{C}$. Trans. Jpn. Inst. Met. 6, 21-30.

Nagamori M. and Yazawa A. (2001) Thermodynamic observations of the molten $\mathrm{FeS}-\mathrm{FeO}$ system and its vicinity at $1473 \mathrm{~K}$. Metal. Mater. Trans. 32B(5), 831-837.

Naldrett A. J. (1969) A portion of the system Fe-S-O between 900 and $1080{ }^{\circ}$ C. J. Petrol. 10, 171-201.

Naldrett A. J. (1989) Sulfide melts-crystallization temperatures, solubilities in silicate melts and $\mathrm{Fe}, \mathrm{Ni}$, and $\mathrm{Cu}$ partitioning between basaltic magmas and olivine, In Ore deposition associated with magmas, (eds. J.A. Whitney and A.J. Naldrett). Rev. Econ. Geol., New Mexico Bureau of Mines \& Mineral Resources 4 (Chapter 2), pp. 5-21. 
Naldrett A. J., Singh J., Krstic S. and Li C. (2000) The mineralogy of the Voiseys Bay Ni-Cu-Co deposit, northern Labrador. Econ. Geol. 95, 889-900.

O'Neill H. S. C. and Mavrogenes J. A. (2002) The sulfide capacity and the sulfur content at sulfide saturation of silicate melts at $1400^{\circ} \mathrm{C}$ and 1 bar. J. Petrol. 43(6), 1049-1087.

Rose L. and Brenan J. (2001) Wetting properties of $\mathrm{Fe}-\mathrm{Ni}-\mathrm{Co}-$ $\mathrm{Cu}-\mathrm{O}-\mathrm{S}$ melts against olivine: implications for sulfide melt mobility. Econ. Geol. 96(1), 145-157.

Shima H. and Naldrett A. J. (1975) Solubility of sulfur in an ultramafic melt and the relevance of the system Fe-S-O. Econ. Geol. 70, 960-967.

Somsiri C. and Gaskell D. R. (1995) The activities of sulfide and oxide components and the solubility of oxygen in copper-ironsulfur-oxygen mattes at $1300^{\circ} \mathrm{C}$. Metal. Mater. Trans. B 26(6), $1157-1164$.
Szentpéteri K., Watkinson D. H., Molnár F. and Jones P. C. (2002) Platinum-group elements-Co-Ni-Fe sulfarsenides and mineral paregenesis in $\mathrm{Cu}-\mathrm{Ni}$-platinum-group element deposits, Copper Cliff North Area, Sudbury, Canada. Econ. Geol. 97, 1459-1470.

Woolrich P., Cowden A. and Giorgetta N. E. (1981) The chemical and mineralogical variations in the nickel mineralization associated with the Kambalda dome. Econ. Geol. 76, 1629-1644.

Yoshiki-Gravelsins K. S. and Toguri J. M. (1993) Oxygen and sulfur solubilities in Ni-Fe-S-O melts. Metal. Mater. Trans. B 24B, 847-853.

Young R. A., Sakthivel A., Moss T. S. and Paiva-Santos C. O. (1995) DBWS-9411 an upgrade of the DBWS** programs for Rietveld refinement with PC and mainframe computers. $J$. Appl. Cryst. 28, 366-367. 